Portland State University

PDXScholar

Summer 8-8-2013

\title{
Lighting the Fire: How Peer-Mentoring Helps Adult Learners Increase Their Interest in STEM Careers: A Case Study at the Community College Level
}

Patricia Marie DeTurk

Portland State University

Follow this and additional works at: https://pdxscholar.library.pdx.edu/open_access_etds

Part of the Adult and Continuing Education and Teaching Commons, Educational Methods Commons, and the Science and Mathematics Education Commons

Let us know how access to this document benefits you.

\section{Recommended Citation}

DeTurk, Patricia Marie, "Lighting the Fire: How Peer-Mentoring Helps Adult Learners Increase Their Interest in STEM Careers: A Case Study at the Community College Level" (2013). Dissertations and Theses. Paper 1095.

https://doi.org/10.15760/etd.1095

This Thesis is brought to you for free and open access. It has been accepted for inclusion in Dissertations and Theses by an authorized administrator of PDXScholar. Please contact us if we can make this document more accessible: pdxscholar@pdx.edu. 
Lighting the Fire:

How Peer-Mentoring Helps Adult Learners

Increase Their Interest in STEM Careers:

A Case Study at the Community College Level

by

Patricia Marie DeTurk

A thesis submitted in partial fulfillment of the requirements for the degree of

Master of Science in Teaching

in

General Science

Thesis Committee:

Michael Flower, Chair

Stephanie Wagner

Cary Sneider

Portland State University

2013 
C2013 Patricia Marie DeTurk 


\begin{abstract}
In the U.S., about 7,000 high school students drop out each school day, representing a loss of talent and ability. Concurrently, there are a decreasing number of enrolled students taking science-related courses at the high school and college levels. Adults, who return to obtain their General Educational Development (GED) certification, are an untapped resource that could be steered toward STEM (Science, Technology, Engineering and Mathematics) careers. In this case study, 15 GED students were shown a STEM video, and then peer mentored by 8 CLA (Clinical Laboratory Assistant) students, in a student-centered laboratory experience. Individual interviews of the GED students prior to and after the treatment were used to assess STEM attitudes. Additionally, the CLA peer mentors were given self-assessments regarding their level of self-efficacy. The most marked difference in the pre- and post-treatment data was with the male GED students. Initially, only 2 of the 7 had definite career goals, 5 with undefined career goals, with 4 showing no interest in STEM. After the treatment, 6 exhibited interest in pursuing STEM education or employment. The female GED students' interest remained unchanged, resulting in the male and female students showing equivalent interest in STEM post-treatment. The CLA peer mentors showed an increase in self-efficacy using Bandura's four sources of self-efficacy in social cognition (1997). The preliminary results of this study suggest that interest in STEM education and STEM careers can be generated with peer mentored learning. (Contains 2 figures and 7 tables.)
\end{abstract}




\section{Acknowledgements}

I would like to thank the students from the GED/ABE and the CLA Allied Health programs at Clackamas Community College for their cooperation during the undertaking of this case study. I would also like to thank all the CCC instructors involved, Helen Wand, Rosemary Teeter and Stephen Long for their valuable input and in allowing me to take over their classrooms. I would like to express my appreciation to my committee members, Cary Sneider, Michael Flower, and especially Stephanie Wagner, for their support and guidance through this process. I also want to thank my dear friend, Harris Hyman, MIT graduate, Fulbright scholar, and self-described "humble surveyor," for reading all my rough drafts and not holding back either praise or criticism. Finally, all thanks and apologies to my children, Rachel and Thomas, and all my friends, especially Dan Dishongh, for all the times I was too busy. But I never stopped caring. 


\section{Table of Contents}

Abstract.......................................................................

Acknowledgements.......................................................

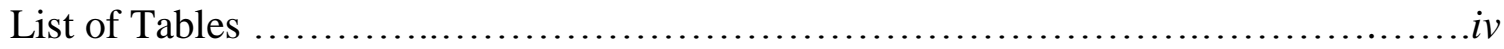

List of Figures.............................................................

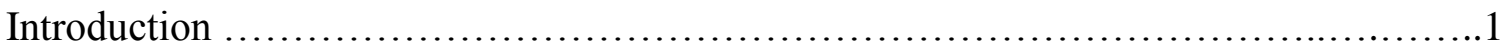

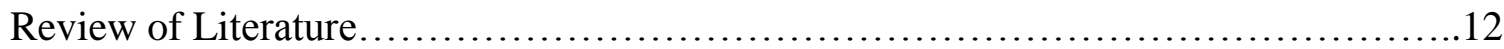

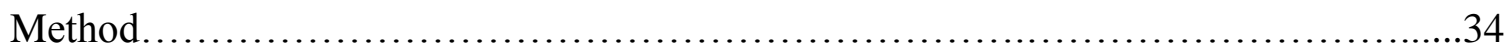

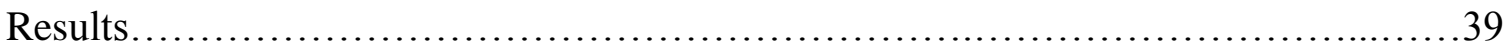

Discussion..................................................................

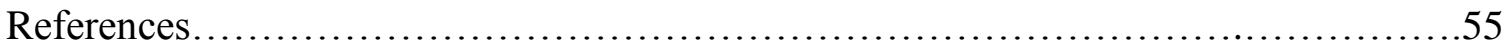

Appendices

A. Pilot Study: Pre-Treatment Questionnaire Results............................58

B. Pilot Study: Pre-Treatment Survey Results.................................60

C. Scoring of the Microbiology Laboratory Tour Video (Pilot) .....................62

D. Pilot Study: Post-Treatment Survey Results................................63

E. Lighting the Fire: Exposure to Science Study Consent Forms.....................64

E.1 GED Student Participant Consent Form

E.2 GED Student Demographics Form

E.3 CLA Mentor Participant Consent Form

F. Exposure to Science Worksheets.......................................69

G. GED Student Participant Demographics (Pilot/Formal Study) ...................73 


\section{List of Tables}

Table 1: Major reasons given to enroll in a GED program ..........................39

Table 2: Post GED Plans (Separated by Gender) ..................................40

Table 3: Interest in Science/Technology Careers (Separated By Gender)...............41

Table 4: What Exercises Did You Like The Best...................................44 What Exercises Did You Like The Least

Table 5: Increased Interest in Science..........................................45

Table 6: Increased Confidence in Science/Technology...........................46

Table 7: Formal Study: Peer Mentor Debriefing ..................................47 


\section{List of Figures}

Figure 1: Percentage of U.S. and Canadian Adults without a High School Diploma......2

Figure 2: Pre- and Post-Treatment Interest in STEM (Separated by Gender)............46 


\section{Introduction}

"Education is not the filling of a pail, but the lighting of a fire." (attributed to) William Butler Yeats

In the U.S., approximately 7,000 high school students drop out each school day (Balfanz et al., 2013), representing a loss of talent and ability. Concurrently, there are a decreasing number of enrolled students taking science-related courses at the high school and college level (PISA, 2007). Together these statistics represent a depletion of workers able to work in science, technology, engineering and mathematics, collectively referred to as STEM. Adult learners, who are motivated to obtain their High School Equivalency, or General Educational Development (GED) certification, for either obtaining better jobs or seek higher education, are an untapped resource that could be steered toward STEM careers. By utilizing this motivation, we can increase the confidence of these students in pursuing post-secondary education in STEM.

As seen in the figure below [Figure 1], as of 2000, there were more than 30 million adults over the age of 16 who were not enrolled in any educational program and did not possess a high school diploma. Of these, only one in one hundred pursued and obtained a GED. Therefore, it can be reasonably stated that 99 out of 100 high school dropouts face difficulty gaining employment or can expect reduced opportunities for career advancement.

In another sense, as society becomes more technologically advanced, ordinary citizens must be able to make increasingly sophisticated science-based decisions. Adults who do not possess at least a high school diploma are at a disadvantage, not only 
economically, but politically as well, because they lack the background to determine what the best choices are for themselves, society, and the planet. Advocates, who stress shortterm fixes or make the best political arguments, can take advantage of a populace

\begin{tabular}{|l|l|}
\hline Figure 1: Percentage of U.S. and Canadian Adults w/o a High School Diploma \\
\hline According to the \\
2000 U.S. \\
Census, there \\
were more than \\
39 million adults \\
(age 16 and \\
older) lacking a \\
high school \\
diploma. Of \\
these, the 2008 \\
GED Statistical \\
Report stated \\
that only one in \\
every 100 \\
attempted and \\
passed all five \\
sections of the \\
General \\
Educational \\
Development \\
(GED) test. \\
\end{tabular}

that cannot effectively dissect evidence with fact-based criteria. Stimulating interest in STEM topics is of benefit to:

- those who need to obtain more education to succeed,

- those who need to make more educated decisions, and

- those who need to be actively involved in how political policy is made. 
The idea for this case study began when Rosemary Teeter, the instructor for the oncampus General Educational Development/Adult Basic Education (GED/ABE) class contacted the director of our Clinical Laboratory Assistant (CLA) program at Clackamas Community College. She wanted to know if we were willing to do a laboratory demonstration for her students and let them look at cells or bacteria under the microscope. She was hoping that this would create interest among her students and improve their GED test scores in science and math. The director of the CLA program, Helen Wand, was amiable to this request and asked me, in my capacity of Adjunct Instructor for this program, if I had any thoughts about how we should proceed. It seemed to be a good opportunity to introduce the GED students to STEM (Science, Technology, Engineering and Mathematics) and promote interest in science/technical careers through a hands-on exercise.

I decided a study should be performed to measure the effects of this intervention. Ms. Wand wanted to include our CLA students to demonstrate their new laboratory skills. I could see that by having the CLA students present, they could act as peer mentors to the GED students, support a student-centered exercise and also provide classroom management. This would also allow us to accommodate more GED students.

Therefore, this case study investigates two research questions; firstly: "Do adult learners in a GED/ABE program increase their interest in STEM as a result of a video/laboratory experience presented by peers? Secondly, "Does acting as peer mentors for adult learners in a laboratory experience increase self-efficacy in CLA students?" The GED program at the Clackamas Community College campus is a 10-week course that covers basic skills, such as reading and writing, as well as competency for taking the 
GED exam. This program provides those who have left high school prior to graduation with the equivalent of a high school diploma. The GED test consists of a battery of tests that include the following STEM sections: Physical Science (which includes Physics and Chemistry), Life Science, Earth and Space Science, and Mathematics. The Clinical Laboratory Assistant program at CCC is a nine-month certificate program, with a new cohort starting each September.

I discussed the vision for this case study directly with our CLA students and asked for suggestions about what they thought would be valuable to share with these students. A number of them had once been GED students, and knew of the struggle it was to reenter school after dropping out. I received valuable input from them about creating an educational and engaging experience. They said they learned a great deal from the hand washing lesson from fall term and wanted to repeat this with the GED students. It had been a low-tech but very informative exercise for them. At that point, I had only thought of two stations, both using microscopes, involving wet mounts and blood films. We discussed how to do a simple wet mount exercise, and agreed that doing cheek cell swabs were easy and relatively non-invasive. They would contribute blood films that they had made from their blood samples collected in class.

Another suggestion, that I discouraged, was to collect blood samples either on themselves or the GED students. That exercise might have been educational, but truthfully didn't meet my criteria of an engaging exercise. Based on these suggestions, I designed a three part student-centered laboratory experience that would include a hand washing exercise (macroscopic), wet-mounting (low-magnification) and examination of 
stained blood films (oil-immersion magnification). The exercises were deliberately designed to shift the focus from the traditional teacher-centered learning to a studentcentered model, using communication and open inquiry to provide a positive science experience (Ketpichainarong et al., 2009). By using the structure of the exercises as a student-centered learning, this would generate a large amount of situational interest since: (1) the novelty of the exercise creates interest; (2) the students develop more interest because they are physically involved with their exercises; (3) they are socially involved with the CLA students, instead of sitting and being instructed.

Mrs. Teeter was impressed with the planned exercises and hoped we would have the opportunity to repeat these with each term's students. She also told us of a YouTube video of a microbiology laboratory tour that she intended to show prior to our planned laboratory experience. Although I hadn't factored in using a video, I decided that the video plus the laboratory experience would be the treatment/intervention in the pilot study.

For the pilot, I developed a pre-treatment questionnaire derived from "Prime the Pipeline Project (P3): Putting Knowledge to Work”, where they assessed students' involvement with modern technology, such as cell phones, podcasts, blogs and finding information on the internet. Their rationale was to modify students' demonstrated interest in technology into interest in STEM careers (Greenes, et al., 2011). The questionnaire I used gauged the exposure to science each GED student had access to, in three areas: (1) Technology; (2) Laboratory: (3) Everyday. Each section had a specific list of tools. The Technology section had choices such as cell phones, Skype, I-Pods and digital cameras. 
The Laboratory section listed items such as microscopes, beakers, safety glasses and scales. The Everyday section had items such as microwaves, food processors and air conditioners. This instrument was also intended to reflect their life experiences, providing validation of the background that these students possessed (Imel, 2000).

The pre-treatment survey, post-video survey and post-lab exposure survey (all the surveys using a 0-5 point Likert scale) were based on The Opinion Panel's “Attitudes to Science: Survey of 14-16 Year Olds" (2010) and the Science Motivation Questionnaire II (Glynne et al., 2011). The intent of the surveys was to gauge interest in science before and after the treatment. I also created station worksheets, with procedures through which the CLA peer mentors would guide the GED students, with blank areas for drawings, plus short open-ended questions. A debriefing group interview with the participating CLA students was arranged to gather observations, and garner suggestions for the formal study to follow.

I spoke with Mrs. Teeter's GED class about the science opportunity that their teacher had recommended, and how I wanted to perform a study about its effects on their interest. I explained that she had chosen a video for them to view, and that the students from the CCC Clinical Laboratory Assistant (CLA) program would assist them with microscopes in our classroom laboratory. The pilot was performed in March 2012 with 10 GED students ( 5 members of this class chose not to participate), with ages ranging from 18 to 52, with 15 CLA peer mentors. The participating GED students signed consent forms and were given the pre-treatment questionnaire and survey to fill out (See Appendix A, B). After I collected the paperwork, Mrs. Teeter showed her selected 
YouTube video. Afterwards, I fielded questions about the video from the GED students and administered the post-video survey (See Appendix C).

The following week, I escorted the participating GED students to meet with their CLA peer mentors in our classroom laboratory on the CCC campus. This was to administer the second part of treatment in the pilot study. The GED students were introduced to the CLA students and divided into 10 work groups of about 1 GED student per 2 CLA students. The three exercises were set up as separate stations so that each student - peer mentor group could rotate from one exercise to another with the provided worksheets (See Appendix F). The GED students would decide how long they would stay at each station, while the peer mentors would introduce the steps of the exercise from the worksheets. Since they would go through the each exercise at their own pace, the GED students would be in control of their learning. Mrs. Teeter, Ms. Wand and myself would be present as observers, but could act as resources as needed.

At the hand washing station, the GED students washed their hands in their normal fashion, rubbed their hands with the provided dye and were instructed to examine their hands inside the black light box to see fluorescence- associated with any lingering bacteria. They were then led through a prescribed hand washing procedure as listed on the worksheet and demonstrated by their mentors. They reexamined their hands under the black light, and then documented the change in the amount of bacteria they saw. At the wet mount station, the peer mentors provided swabs for the GED students to rub the inside of their cheeks. The mentors then made wet mounts from the swabs, so the students could see their cheek cells under 10x and 40x magnification. The GED students 
were encouraged to draw pictures of their cheek cells under each magnification. At the blood film station, the CLA mentors found different types of white cells from the prepared blood slides for their students, using 100x magnification; the GED students were encouraged to draw these as well. These worksheets were not graded, because of the focus was on a positive experience and not on an actual gain in knowledge (Glowinski \& Bayrhuber, 2011). The GED students then filled out the Post-Treatment surveys (See Appendix D).

In reviewing the process used in the pilot, I decided to eliminate the pre-treatment questionnaire used in the pilot, because of the concern that asking about the use of technology in everyday life should be considered part of the treatment and not as an assessment instrument. Also, the data gathered would not alter the format of the study or add to my understanding of the effectiveness of the treatment. The surveys were changed to pre- and post-treatment interviews. Making this change allowed me to gauge individual impressions more vividly and accurately.

The choice of YouTube video was changed from a tour of a microbiology laboratory to Beyond the Lab: Careers in Science where six international students, with different interests in STEM, discussed the careers that continue to motivate them postgraduation. The intent in changing the video was to generate interest in STEM that was not exclusively about lab work, as well as giving personal perspectives of how these students found relevance for pursuing the interests they had. The original video would be better suited for the CLA students at the beginning of their orientation, since the focus was on how the laboratory departments were arranged and how samples traveled to their 
assigned areas within the microbiology laboratory. The new video included scenes from a planetarium, a video game creation studio and an aquarium. The post-treatment CLA student group debriefing was augmented to include written assessments of both the GED students' and their own experience. The laboratory exercises themselves were the same ones we had developed for the pilot, and the prepared worksheets remained unaltered.

During the pilot, it was difficult for the GED students to transition away from the blood film station, compared to the other two stations. The students who had completed the hand washing and wet mount stations had to stand and wait. The peer mentors didn't know how to deal with the increasingly awkward situation, and ran out of things to talk about. I decided that we had to avoid a repeat by having this year's CLA students set up 10 microscopes with the prepared blood films, instead of the three used in the pilot.

Since each section of the GED exam is tested separately, the sections are taught in a rotating manner through the school week. The students focus on the sections they are lacking, which leads to sporadic attendance. The new GED instructor, Steven Long (Mrs. Teeter had retired) pointed out that attendance was also affected by home and job issues. In order to recruit as many GED participants as possible, it was necessary for me to introduce my research project to the class on three separate occasions.

All the GED student participants were interviewed prior to the video about their reasons for pursuing their GED certification, their personal career and education goals, and if they had any interest in science or technology. The interviews took place over the course of two weeks. Because of the previously mentioned attendance issues, I was also 
asked to do an introduction and interviews for two new participants just prior to showing the video. This formal case study included 15 GED students and 8 CLA peer mentors.

The 15 participating GED students watched the selected video, then the next day were escorted to the classroom laboratory to meet with our CLA students, who had set up the three stations, one for each laboratory exercise. Because the GED to CLA student proportions in the formal study were different from the pilot (15:8), most of the groups had two GED students to one CLA mentor. The three lab exercises were set up in the same format as the pilot, as separate stations so that each student-mentor group could rotate at will with their provided worksheets. The intent was that the GED students would still determine how long they would linger at each stage, again without prompting.

The CLA peer mentors aided the GED students in navigating the steps of each station in turn, while Ms. Wand and I acted as observers of the experience, as we had done for the pilot. The GED students, with their peer mentors, proceeded through the three stations as was done the previous year in the pilot. At the end of the exercises, I collected and examined the station worksheets before returning them to the GED students. As with the pilot, I did not grade them.

When the laboratory treatment was completed, I interviewed each of the GED students back at their classroom over the course of the following week. This posttreatment interview was to determine if any increase of interest in science or technology had been elicited, and if there was any concomitant interest in STEM careers from the video, the laboratory experience or the presence of the CLA student mentors. I also did a group debriefing with the CLA mentors. Additionally, I requested that the mentors make 
written assessments as to whether or not they could perceive interest in science by the GED students, using a list of questions I had provided them [Table 10].

\section{Hypotheses:}

1.) By providing a positive and supportive laboratory experience, through the use of peer mentors, GED students will gain confidence in science-related activities and seek enrollment in health careers.

2.) By acting as peer mentors, the CLA students will improve their self-efficacy through the opportunity to demonstrate their knowledge. 


\section{Review of the Literature}

The following review of the literature relevant to this study includes papers on: how the GED degree meets the needs of adult learners, career and technical programs, the special needs of adult learners, motivation, student-centered learning, and peer mentoring.

\section{Pursuing the GED: Bridge to Postsecondary Education/ Special Needs of Adult}

\section{Learners}

"An Analysis of Rural and Urban Pennsylvania Adults Taking, Completing and Passing the GED”, was conducted by Van Horn and Kassab (2011) to identify similarities and differences among rural and urban GED candidates. The participants in their study were 68,317 Pennsylvania residents who were no longer enrolled and had not received a high school diploma or equivalency certificate. Overall, the average age of participants was 24, and 52\% were female. Preparing for and taking the GED was the treatment. The researchers created longitudinal databases containing data for the period of January 1, 2003 to December 31, 2008.

Van Horn and Kassab found that rural residents were more likely to be GED completers and GED passers than urban candidates, though they scored significantly lower. It was indicated that candidates who used official GED practice tests through an adult education class rather than home study scored higher than those that used home study. The researchers also found that GED candidates were more likely to learn about the testing and other services through family, friends and neighbors than from official government agencies. Their study confirmed the 2000 U.S. Census finding that a significant number of adults without a high school credential did not become GED 
candidates. Their study results also correlated with the 2008 GED Statistical Survey for U.S. and Canadian Adults [Figure 1]. The authors determined that if state agencies more actively promoted as well as redesigned their programs, more adults would be able to take and excel on the GED, improving their economic status.

"GED Candidates and Their Postsecondary Education Outcomes: A Pilot Study", was conducted by Patterson, Song and Zhang to establish a baseline to measure the effectiveness of GED 20/20. GED 20/20 is a new government initiative to transition adults without a high school diploma to the GED credential and career and college readiness via accelerated learning. The goal of GED 20/20 is to increase the number of adults with college degrees by the year 2020 .

The hypotheses tested by Patterson, Song and Zhang in this pilot study are:

- Candidates that obtain their GED with the intent of enrolling in postsecondary education are more likely to do so than candidates who do not express this intent;

- GED candidates are more likely to enroll in postsecondary education than nonGED takers;

- GED scores earned determine the level of success of those who enroll.

In 2008, Patterson, Song and Zhang created a cohort of 1000 GED candidates chosen at random who had taken the GED in the calendar year 2003. This cohort included all examinees, whether or not they passed the GED at that time. This sample was matched with the postsecondary outcome, focusing on enrollment, persistence, and completion. All data was quantitative. The random collection did not differentiate among personal characteristics or credential status. The data included enrollment starting dates and end 
dates, enrollment status, attendance status (full or part time), degrees, and majors. There were 637 GED credential recipients, 363 GED non-passers for a total number of 1000 , with a mean age of 20. The treatment was taking the GED and pursuing postsecondary education during the course of the five year study.

Patterson, Song and Zhang found that there was a positive relationship between obtaining the GED and enrolling in postsecondary education, especially among candidates who indicated their intent to attend a two-year or four-year college as a reason for obtaining the credential. Also, GED recipients were more likely to enroll in postsecondary education than GED non-passers, and that women who passed the GED enrolled at a higher rate than their male counterparts. There was also a positive relationship between higher GED scores and postsecondary enrollment. However, the researchers also found that $77 \%$ enrolled for a single semester only, and those that do graduate take longer (3.8 years on average for a two year program) to do so.

\section{I-Best / Career and Technical Education (CTE) programs}

In "Education; outcomes of I-BEST, Washington State community and technical college system", Jenkins, Zeidenberg and Kienzl examined the effects on educational outcomes by adult students participating in I-BEST (Integrated Basic Education and Skills Training program). The study took place over the span of two years. I-BEST students' outcomes were compared to those of other basic skills students not enrolled in I-BEST. A study taken prior to the introduction of the I-BEST program (Prince \& Jenkins, 2005) found that only $31 \%$ of a cohort of basic skills students in ABE/GED programs earned at least 1 credit in 5 years, with the rate for ESL students to be $12 \%$. 
The hypothesis advanced by Jenkins, Zeidenberg and Kienzl was that blending basic skills instruction with college-level career-technical skills would allow these adult students to persist in their academic progress. Research indicating that adult learners are more able to learn basic skills when the material has context, compared to other courses taken (Resnick, 1987) inspired this program design.

Jenkins, Zeidenberg and Kienzl considered the treatment to be enrollment in IBEST during the academic year 2006-2007, with tracking of students continuing into the next academic year, rather than completion of the program. The participants were 896 IBEST students, who were enrolled in 24 community colleges during the academic year 2006-2007, with a mean age 32.5. One group used for comparison included 1356 students that were taking workforce courses but were not enrolled in I-BEST (Non-IB Workforce students) with a mean age 31.9. A second group used for comparison were 28,826 students enrolled in non-workforce courses and not enrolled in I-BEST (non-I-BEST non-Workforce students), with a mean age of 32.3 , generating a total number of 31,078 individuals studied. The researchers collected administrative data and performed multivariate analyses on both I-BEST and non-I-BEST students enrolled anytime during the academic year 2006-2007 within Washington State's community and technical college system.

The I-BEST study encompassed 24 member colleges the first year, then expanded to all 34 member colleges the second year. Jenkins, Zeidenberg and Kienzl found that participation in I-BEST correlated with better educational outcomes over the two year tracking period. Causation could not be assigned due to the non-random selection of 
participants, especially in regards to the construct of motivation. They advised follow-up studies to address these concerns. However, the participants were substantially more likely (55\%) than non-participating adult basic skills students (16\%) to advance to a college-level workforces program and earn at least one year of college credits and a credential.

Alisha Hyslop begins her article, "CTE's Role in Science, Technology, Engineering and Mathematics," with the statement that the U.S. has a diminishing pool of workers that are qualified to work in STEM (science, technology, engineering and mathematics) careers, which are expecting a further reduction of qualified workers due to retirement. She believes that through the creation of Career and Technical Education (CTE) programs, students who choose this non-traditional career path, combined with active career exploration and advising, can develop interest in the multiple careers that are encompassed within STEM. A number of successful strategies have been implemented in these programs, including:

- Career guidance

- Role models and mentors

- Hands-on activities to engage students and connect to real-world programs

- Cohort-based activities

Hyslop points out that through a combined effort by government, educators and industry, disadvantaged students are being actively recruited to participate in CTE-STEM programs, which include work-based opportunities such as job-shadowing and internships. By understanding the opportunities generated by STEM, and having the 
concepts adequately scaffolded, adult learners can go on to seek four-year degrees at STEM-strong colleges.

\section{Special Needs of Adult Learners}

Ruth Ashmore begins her article, “The Adult Learner: Implications and Activities for Implementation" (1987), by stating that Adult Learners need teaching strategies tailored to characteristics that distinguish them from younger learners. She further separates these adult learners into two groups, the Traditional and the Non -Traditional student. The focus of the article is the non-traditional student, who has begun college after the age of 22. These non-traditional students differ from their peers with their divergent life experiences and world views, necessitating alternate methods of instruction. According to Ashmore, non-traditional students are not served by existing pedagogic methods due to their independence, increased motivation and focus on learning. They are not likely to be as dependent and compliant in the classroom situation. Since these students are self-directed, they learn better when they can relate the content of the lesson to perceived need, making choices about that which they wish to learn.

In the two-part article by Whiting, Guglielmino and Burrichter, "Adult Development. What do Teachers of Adults Need to Know?'(1988), adult learners must continuously develop to retain mental flexibility through changes in jobs and changes in society. The educator is challenged to provide opportunities for growth, taking into consideration how the needs of adult learners differ from traditional teaching methods. The authors stress the importance of matching or challenging the developmental level of these students. The first half of her article outlines the four basic assumptions, as presented by Knowles (1974), of the educational needs of adult learners: 
- They are more self-reliant and less dependent on external forces to determine educational path;

- They possess unique life experiences that can augment learning, as well as provide identity;

- They are prepared to learn at the developmental level they have achieved;

- They learn better if the context of their learning adds to their base of knowledge, and is not arbitrarily imposed.

The second half of the article is a dialogue regarding specific theories of human development, relevant to the educational and sociological needs of the adult learner. This discussion benefits the reader in determining the type of appropriate scaffolding.

\section{Situational Interest / Motivation: Extrinsic and Intrinsic}

In "Student Interest Generated during an Inquiry Skills Lesson" (2009), David Palmer defined motivation as "any process that initiates and maintains learning behavior". Motivation acts as a catalyst to the learning process. He quotes Rosalind Driver from her article, "Students' Thinking and the Learning of Science: A Constructionist View" (1989), that learning as "an active process which requires effort on the part of the learner." Students must be inspired to start learning, and then require continued motivation until learning is accomplished. When applied to the learning of science, this expectation is at a disadvantage because of the perception that science is not enjoyable. If students cannot be motivated to learn science, then learning is incomplete. The possibilities inherent in scientific inquiry include the opportunity for the students to 
actively develop their own lines of inquiry and exploration, which would allow them to discover what interests them on a personal level.

Palmer attempts to pinpoint effective educational tools that motivate students to study science. The educator needs a "hook" that draws in the student and generates interest. The concept of "interest" has been separated into two types by Hidi (1991): personal interest, which is presented as a "long-term preference for a particular topic or domain" and situational interest, which is defined as "short term interest that is generated by aspects of a specific situation”. He cites a study by Mitchell \& Gilson (1997) where they observed that repeated events of situational interest have led to personal interest.

The purpose of Palmer's study is to determine how much situational interest is generated during different parts of a science lesson and the sources of that interest. In this study, 224 ninth grade students ages 14-15 were gathered from 5 separate schools. The study was focused on eight students from each class (4 boys and 4 girls). Each group of eight students participated in a single 40-minute science inquiry class. This exercise was performed with 28 groups using the same instructor. Each exercise was based on a short and simple format where students would perform a small number of skills, such as proposing questions for study, working out experiments, observing results and verbally reporting results. The four phases were Demonstration, Proposal, Experiment and Report. Quantitative measurement using a Likert scale was performed between each phase to measure situational interest. Qualitative data was collected from audiotaped group interviews that were conducted at the end of each lesson. According to Palmer, situational interest could be observed qualitatively and quantitatively in students introduced to scientific inquiry. First, the novelty of the exercise created interest 
(suspense). Secondly, the students developed interest because they were physically involved with their experiment as well as being socially involved with their classmates, instead of sitting and being instructed.

Wolters and Pintrich performed their correlational study, "Contextual differences in student motivation and self-regulated learning in mathematics, English, and social studies classrooms," (1998), to determine the differences in the students' level of motivation and self-regulated learning for the subject areas of mathematics, social sciences, and English, if any relationship between these constructs can be observed, and the role of gender. The hypothesis advanced by Wolters \& Pintrich is that males would report higher efficacy beliefs in mathematics, where females would report higher efficacy beliefs in English, also that females would report higher levels of self-regulation than males.

Wolters and Pintrich's study included 545 seventh and eighth grade students from a junior high school in a working class suburb of a Midwestern city. There were 280 females (51\%) and 265 males (49\%), ages 11-15 years (mean age 12.6). Six mathematics teachers, six English teachers, and five social studies teachers taught the target classes. All the students completed a self-report questionnaire in late October, derived from a previous questionnaire created by the co-author (Pintrich et al., 1993). This instrument assessed different facets of student motivation and cognition. A seven-point Likert scale was used to assess each question as presented in context of four different subject areas (mathematics, English, social studies, and science). In this questionnaire, students were asked to rate the value and their interest in each subject, how confident they were about their performance, and any anxiety they experienced during tests. 
Wolters and Pintrich found that students who reported high task value for a particular subject were more likely to use deeper processing methods and more selfregulatory strategies. However, actual grade performance was more likely to be predicted by the level of self-efficacy; this was consistent in all three subject areas, regardless of gender.

Domene, Socholotiuk and Woitowicz (2011), examined quantitatively the effects of career outcome expectations (COE) and aspiration to enter a STEM career on postsecondary motivation in "Academic motivation in post-secondary students: Effects of career outcome expectations and type of aspiration." This study was designed to establish if students' COE are linked to their sense of intrinsic and extrinsic motivation for their program of study. Intrinsic motivation here is referred to as an internal drive through a desire for knowledge. Conversely, extrinsic motivation is referred to as the drive to perform to gain acknowledgement and "maintain socially important values." The authors cite Peetz et al (2009) that if first-year undergraduate students were persuaded to think about graduation and their life goals more imminent to their present state, they showed higher levels of academic motivation than those persuaded to think of graduation as more remote. It was hypothesized that students with high expectations for a successful career outcome would have higher extrinsic motivation than their peers with low expectations. In contrast, no such effect was anticipated for the effect of career outcome expectations on intrinsic motivation. The participants are students (72.4\% female/27.6 male), ages 1725 (age mean 20.43), enrolled in post-secondary education (undergraduate, graduate, trades certification, diploma, or other). The treatment was enrollment in post-secondary education. The researchers collected data online anonymously using the Academic 
Motivation Scale (Vallerand et al., 1992, 1993) which assessed extrinsic and intrinsic motivation for engaging in the targeted programs of study, using a 28-item, self-report, 7point Likert scale. Career outcome expectations were measured using McWhirter's Vocational Outcome Expectations scale, which is designed to assess the subject's sense of being able to achieve a successful vocational outcome (McWhirter et al., 2000).

Domene, Socholotiuk and Woitowicz found that participants with high COE had higher levels of extrinsic motivation than those in the low COE group. Students aspiring to a STEM career were more externally motivated than their peers who aspired to other career paths. STEM students had higher levels of intrinsic motivation than non-STEM students, but the effect size was not as significant as the effect of COE. The researchers indicated that this design was limited by the use of self-report methods. Thus, the results reflect the participants' perceptions of themselves, and there may be discrepancies between actual and reported experiences of $\mathrm{COE}$, intrinsic, and extrinsic academic motivation. The authors thought that it was possible that students with low levels of motivation were under-represented in the study, but felt that there was sufficient empirical support to justify developing interventions to promote COE and STEM aspirations, in an effort to enhance academic motivation.

\section{Situational Interest / Intrinsic Motivation}

In their literature review, "Motivating the Academically Unmotivated: A Critical Issue for the $21^{\text {st }}$ Century" (2000), Suzanne Hidi and Judith Harackiewicz discussed ways educators could enhanced learning through externally triggered situational interest and extrinsic motivation. They cite studies that show as students' attitudes toward subjects such as math and science deteriorate as they leave childhood and enter adolescence. In 
order to "turn on" students the authors suggest that by focusing on interest and goalsetting would promote greater learning. They cite Schraw \& Dennison's (1994) findings that suggested that when the students are assigned reading tasks, they showed greater recall when the text contained more meaningful and relevant than texts that had no such relevance. Additionally, to motivate students to obtain mastery skills, Hidi \& Harackiewicz go on to quote White (1959) and Deci (1975) in their assertion that educational materials should promote autonomy and self-determination, through providing more choices and challenges. Since individuals who are interested in specific activities are more likely to "pay closer attention, persist for longer periods of time, learn more and enjoy their involvement," The authors suggest that the by the use of situational interest, motivation could more easily generated in students that show no personal interest in learning.

In "Student Labs on a University Campus as A Type of Out-of-School Learning Environment: Assessing the Potential to Promote Students' Interest in Science,” (2011), Ingrid Glowinski and Horst Bayrhuber gave questionnaires to 378 upper secondary students following a student lab. The students were aged 17 to 19 , with $40 \%$ male and $60 \%$ female. Their intent was to answer the following research questions:

- Can the student lab characteristics described (practical work, authentic learning environment) be identified as separate efficacy factors causing students' situational interest?

- Which attributes of students (prior individual interest, self-concept, gender) trigger situational interest? 
- Which reciprocal effects are shown by the students' situational interest in lab characteristics with the degree of pre-visit instruction about the subject?

The student lab was located on a university campus. The students stayed for six hours for one day together with their school instructor. The majority of the day was spent performing experimental activities in small groups, with one of the university scientists acting as lab instructor. After the lab experience, all the students were given a 48 item questionnaire, with a 1 to 4 Likert-type scale.

Glowinski \&Bayrhuber found that the students' sense of competence was a significant factor in predicting interest. Students that initially showed low individual interest in science resulted in high situational interest and a high level of social relatedness. Gender had no relevance on interest in the student lab. The authors concluded that outreach programs seem to promote engagement with science in students, through learning experiences not used in traditional classrooms, such as practical work within an authentic learning environment.

\section{Student-Centered Learning: Mastery Goals v. Performance Goals}

Deci \& Ryan (1993) identified three basic needs (autonomy, social relatedness, and competence) as emotional experiences which are related to the development of interest (Krapp, 2005). By attempting to create interest in a previously introduced content, such as science, where the student has not had these basic needs met, the instructor is at a disadvantage by the student's reluctance to reengage. By reintroducing the student to science using student-centered learning, there is the opportunity for the student to establish autonomy and competence within a supportive social context (Glowinski \& Bayrhuber, 2011). 
In their study, "Motivational Influences on Student Participation in Classroom Learning Activities" (2004), Julianne Turner and Helen Patrick examined how classroom participation is affected by students' perceptions and goals, in context with classroom structure. Using observational research, they investigated how middle school instructors communicated their classroom goal structures. In the traditional teacher-centered learning model, the focus and content of the learning is determined solely by the teacher. Embedded in this learning style, according to the authors, is the message is that active participation by the student in their learning is not required; emphasis on correct answers or following directions, takes the place of encouraging questions that lead to understanding.

Turner \& Patrick's hypothesis was that students would be more willing to participate in classrooms where teachers expressed enthusiasm about learning, communicated a belief that all students can learn, and provided academic and emotional support for students' understanding. Turner \& Patrick focused on two students, garnered from a concurrent study involving students from the same classes, who started in the same sixth grade mathematics class; one moved into an average seventh grade mathematics class, while the other progressed into an accelerated prealgebra class. Their research question was, "How do personal level factors (math achievement, personal goals, perceptions of teacher support, perceptions of the classroom goal structure) and features of the classroom context (teachers' instructional practices, average perceptions of classroom goal structures) help explain students' participation in both years?" The treatment was enrollment in the observed sixth and seventh grade classes. 
One instrument used by Turner \& Patrick was a survey, administered during spring term of both sixth and seventh grades, which measured students' personal achievement goals, perceptions of teacher support and the goal structure (derived from Patterns of Adaptive Learning Survey, Midgley et al, 1996) using a 5-point Likert-type scale. The second instrument was direct classroom observation, with 5 lessons observed in fall and 5 in spring during the sixth grade class, and 3 lessons in the fall and 3 in the spring during the seventh grade class. Additionally, the sixth grade class took the state achievement test and in seventh grade they took a nationally standardized test, with scores collected from school records at the end of each year. The classroom discussions by the teachers were coded using three broad a priori categories: instructional, motivational, and organizational, which were then divided into "supportive" and "nonsupportive". Based on 10 observations, the researchers calculated percentages of supportive vs. non-supportive classroom interactions for each teacher.

Turner \& Patrick found that teachers who emphasized performance goals, correctness and relatively low motivational support over mastery goals discouraged lower achieving students' participation in class and lead to avoidance behaviors, and cited previous research that indicated a ratio of 20 to 1 (supportive to non-supportive discourse) promoted mastery goals over performance goals (Turner et al., 2002). They also found that students exhibited mastery goals when they showed interest and diligence when working on a task or expressed excitement when learning new skills or knowledge, especially when the instructor also exhibited excitement about the subject. 


\section{Peer Mentoring / Self-Efficacy Skills}

Peter Barbatis, in his study, "Perceptions of Underprepared Community College Students Regarding their Educational Achievement: Preliminary Analysis of a Pilot Study" (2008), hypothesized that students' inability to connect with their peers contributes more to their decision to leave school than any other cause. His research question was, "How do underprepared community college students, who participated in a learning community, completed their developmental classes, and graduated from their programs of study or successfully transferred to the upper division, perceive their experiences in the community college?" He cited three theoretical frameworks for his study: academic integration theory (Tinto, 1975), social involvement theory (Astin, 1985) and critical theory (Freire 1970, 1992; Horkheimer, 1982; McClaren \& Hammer, 1989). For this study, volunteers were garnered from the pool of underprepared college students whose scores on standardized tests required them to enroll into all three available remedial classes, English, Reading, and Mathematics. Approximately 25 students per school year (2003-2008) have participated. The treatment was their enrollment in the three remedial classes, and their subsequent persistence or non-persistence in higher education. The researcher acted as an observer; the instruments involved individual and group interviews, with an external audit trail was applied to the research log, the verbatim transcripts, the coding procedures and the identification of themes. Because the author was concerned that his data could potentially be affected by his role as dean of students, he stressed to the participants the importance that their experiences be communicated as honest and frank as possible. 
Barbatis found that $68 \%$ of the participants completed the required remedial classes and enrolled in credit-bearing classes. Over the course of the study, he found that seven students (7\%) graduated with an associate degree or transferred to a university. 13 students completed their remedial classes and earned 30 credits, while 51 students withdrew. A review of the data indicated that most of the 7 graduates needed to retake their remedial math classes, college-level algebra, and science classes. Also, these same students showed a strong sense of persistence, responsibility and possessed concrete goals.

Among the negative influences identified by Barbatis were the developmental classes that were taught with techniques that resembled high school, with the subjects taught in an abstract manner without context to everyday life or to other courses taught in community college. The author quotes one of the students who went on to graduate, “after I graduated, I talked to one of my friends...that I went to high school with and I told her that I graduated and everything and she asked me if I took any prep classes and I said, "Yeah, I took a couple of prep classes", and she said she feels that people that take prep classes...it's like they're never going to graduate. ...the prep classes make the students feel like...it's going to take them forever to get out..."

Among the influences that aided persistence, Barbatis cited connection to family, peers, and supportive faculty. He found modeling to be essential for student success, as well as co-curricular activities that were incorporated in to the classroom, especially if the activities were tied to the students' majors. Among his recommendations was to create groupings or cohorts of students with the same major to provide peer support 
relationships. Another was to create courses with modules focused on specific competencies in order to give students a sense of progression and a level of success.

The purpose of Lori Goff’s study, “Evaluating the Outcomes of a Peer-Mentoring Program for Students Transitioning to Postsecondary Education” (2011), was to evaluate a peer-mentoring program that had been developed at an Ontario university using an objectives-oriented approach to determine whether the program had value and should be continued as is, continued with improvements, or terminated. The program being studied had been created to help students transit from high school to college, achieve better outcomes in their first year biology courses, and help them select their upper division biology programs. Her goal was to provide evidence as to whether this program met all three of these objectives.

Goff's research was conducted within the biology department of a mid-sized Ontario university, with the participants garnered from all students enrolled in the introductory biology course offered each fall semester for the years 2003 to 2007 . Her hypothesis was that some of the protégés would choose biology programs for their study options based on the influence of the biology peer mentors. Data was collected from 1200 to 1500 students per academic year. The treatment was attendance of up to five peermentoring sessions during one of the fall term biology courses. The instruments were: survey data from a post-treatment questionnaire, academic records, and attendance records for the peer mentoring sessions. Peer mentors were obtained from $3^{\text {rd }}$ and $4^{\text {th }}$ year students enrolled in a specially created upper division course designed to provide leadership, teaching and mentoring experience. 
Goff found that peer mentoring was successful in supporting the academic needs and growth to first year students, but had no evidence that suggested that the program had any effect on creating more biology majors. She suggests modifying the program to involve strategies that engage students through their personal motivations, beliefs and goals.

DeChenne, Enochs and Needham, in their study, "Science, Technology, Engineering, and Mathematics Graduate Teaching Assistants Teaching Self-Efficacy" (2012) explored self-efficacy in the teaching skills of STEM graduate teaching assistants (GTAs) because of their impact on the scientific literacy of undergraduate students, plus the knowledge and retention of STEM majors. The purpose of their study was to develop an instrument for measuring self-efficacy of STEM GTAs, and to explore relationships between STEM GTA teaching self-efficacy, teaching professional development and teaching experience. They quote Bandura (1997), regarding his four sources of selfefficacy in social cognitive theory:

1. Master experiences - self-evaluation of performance (of task)

2. Vicarious experiences - Modeling by peer

3. Verbal persuasions - Feedback

4. Psychological states - emotions while performing task (calmness, anxiety, excitement)

DeChenne, Enochs and Needham collected data from six U.S. universities from various STEM departments, with 253 participants. 68\% were engineering GTAs, with $32 \%$ from science and mathematics. $25 \%$ indicated their primary role was grading, with $75 \%$ indicated their role as classroom instruction. $17 \%$ were female, $47 \%$ were 
international teaching assistants (ITAs) and 64\% expressed interest in pursuing college teaching as a career. $67 \%$ had less than two years teaching experience. The instrument used was adapted from College Teaching Self-Efficacy Scale (CTSES) (Prieto \& Navarro, 2005). They streamlined the CTSES by modifying items from the general instructor context to items more specific to STEM GTA teaching and removing items not related to STEM GTA teaching. Of the two sections of the CTSES, they removed the section measuring actual instructor action and retained the self-efficacy section, plus they reduced the Likert-type scale from six points to five, because they chose to use a scantron bubble form for data collection. The data was collected from the various sites from fall 2008 through fall 2010 , once, near the end of the semester or quarter.

DeChenne, Enochs and Needham found that teaching self-efficacy did not vary by gender, career plans, college of instruction, or instructional role. The one group difference was with the ITAs, who has significantly higher instructional strategies selfefficacy than the U.S. GTAs. The overall teaching self-efficacy, however, was similar. The researchers felt confident that their instrument provides an evaluation tool to assess the relationship between the STEM GTAs self-efficacy and their ability to create an active and positive learning environment.

\section{Literature Summary}

There is an overwhelming need for programs that empower adults who lack a high school diploma to obtain their GED and develop persistence in obtaining higher education (Yan, 2002). More adults would be able to take and excel on the GED, improving their economic status, if they were better informed and received appropriate 
counseling (Van Horn \& Kassab, 2011). Because adult learners require a connection between their lives and the studies they are required to take, a perceived lack of relevance between studies and future life goals can be addressed through educational intervention before the adult learner chooses to withdraw from a course of study. Students who have definite career goals when they pursue their GED are more likely to enroll in higher education, but the retention rate is extremely low, with $77 \%$ leaving college after only one term (Becker Patterson et al., 2008). This sobering statistic requires the creation of strategies to assist the adult learner with academic persistence, especially to address the low numbers of students seeking STEM educations. Hyslop (2010) suggested several tactics, including role models/mentors and hands-on activities. By blending basic skills instruction with college-level, career-technical skills as shown in the I-BEST program, adult learners acquire the appropriate learning strategies to persist in their academic progress (Jenkins et al,, 2009, Resnick, 1987). Adult learners who have acquired negative experiences in teacher-centered learning have developed performance goals instead of mastery goals. By providing a shared learning experience through the use of peer mentors, both groups gain autonomy, social relatedness and competence. There may be sufficient studies to justify developing interventions to promote COE and STEM aspirations, in an effort to create self-efficacy (Domene et al.,2011) Outreach programs seem to promote engagement with science, through learning experiences not used in traditional classrooms, such as practical work within an authentic learning environment (Glowinski \& Bayrhuber, 2011). Adult learners, who are motivated to obtain their GED to see better jobs or higher education, can be steered toward STEM careers by increasing their confidence in pursuing higher education. 
By generating interest in STEM through this study, I believe that the adult learner can find sufficient relevance in pursuing a career in STEM. Additionally, the CLA students, acting as peer mentors, can increase their self-efficacy in their course of study, through Bandura's four sources of self-efficacy Mastery, Modeling, Feedback and Emotions (1997, DeChenne et al., 2012). My hypotheses in this study are, first, by providing a positive and supportive laboratory experience, through the use of peer mentors, GED students will gain confidence in science-related activities and seek enrollment in health careers; secondly, by acting as peer mentors, the CLA students will improve their self-efficacy through the opportunity to demonstrate their knowledge. My research questions are: "Do adult learners in a GED/ABE program increase their interest in STEM as a result of a video/laboratory experience presented by peers? and "Does acting as peer mentors for adult learners in a laboratory experience increase self-efficacy in CLA students?" 


\section{Method:}

\section{Overview}

The research design relied on a case study approach to gauge the level of interest in STEM education and careers in GED students prior to and after viewing a STEM video and participating in a laboratory experience with peer mentors. This study also intended to assess the amount of self-efficacy exhibited by the peer mentors about their knowledge of the clinical laboratory after the experience. The research questions to be answered in this study were:

1. "Do adult learners in a GED/ABE program increase their interest in STEM as a result of a video/laboratory experience presented by peers?" and

2. "Does acting as peer mentors for adult learners in a laboratory experience increase self-efficacy in CLA students?"

The independent variables were:

1. A STEM video coupled with a peer-guided laboratory experience for the GED students;

2. A peer mentorship experience for the CLA students.

The dependent variables were:

1. increased interest in STEM in the GED students, as measured by pre- and posttreatment interviews;

2. increased self-efficacy in the CLA students after acting as peer mentors in a laboratory experience.

In this study, 15 GED students and 8 CLA students signed consent forms in order for data to be collected. The CLA students were coached as to their role as peer mentors 
in anticipation of the arrival of the GED students for their laboratory experience and preparation required for the three stations to be used. The 15 GED students were interviewed about their goals and attitudes about STEM prior the viewing the STEM video. The day after the video was shown, the GED students were escorted to the classroom laboratory and introduced to the CLA students who would act as their peer mentors. All participants were given the unit worksheets [Appendix G]. The GED students, in combination with their mentors, worked through the three stations. Afterwards, the peer mentors attended a debriefing and were asked questions about the experience [Table 9]. All GED participants were interviewed during their next class session to assess their reactions to the video and laboratory experience.

\section{Site and Participant Selection}

This research was conducted at the Harmony campus of Clackamas Community College, within the GED classroom and the classroom laboratory for the Allied Health programs. Participants included all students registered for the GED program for this location offered in the winter term of each year.

The following diagram summarizes the intended research design.

$$
\begin{aligned}
& \begin{array}{llll}
\mathbf{N}_{\mathrm{GED}} & \mathbf{O}_{\mathrm{I} 1} & \mathbf{X}_{\mathrm{L}, \mathrm{V}} & \mathbf{O}_{\mathrm{I} 2}
\end{array} \\
& \begin{array}{lll}
\mathbf{N}_{\text {CLA }} \quad \mathbf{X L}_{\mathrm{L}} & \mathbf{O}_{\mathrm{D}}
\end{array} \\
& \mathbf{N}_{\mathrm{GED}}=\text { GED Group, nonrandomized } \\
& \mathbf{N}_{\text {CLA }}=\text { CLA Group, nonrandomized } \\
& \mathrm{Xv}=\text { STEM Video }
\end{aligned}
$$


$\mathrm{X}_{\mathrm{L}}=\mathrm{Lab}$ experience

$\mathrm{O}_{\mathrm{I} 1}=$ Pre-Treatment Interview

$\mathrm{O}_{\mathrm{I} 2}=$ Post-Treatment Interview

$\mathrm{O}_{\mathrm{D}}=$ Peer-Mentor Focus Group Debriefing

Participants. The participants for Group 1 were adults enrolled in a GED prep class at Clackamas Community College. The participants for Group 2 were peer volunteers from the Clinical Laboratory Assistant 1 Year Certificate (Allied Health) program at Clackamas Community College. The instructor was the researcher.

How Selected. The test subjects for Group 1 were 15 adults who are enrolled in a preGED class who had elected to participate in an after-school exercise assessing their scientific interest. The test subjects for Group 2 were 8 adults out of 15 enrolled in the CLA program who elected to participate in an exercise during scheduled laboratory time assessing their self-efficacy.

Demographics. The test students were adults returning to the academic venue to obtain their GED. Their ages ranged from 18 to 45, with 7 males and 8 females. 3 were white, Hispanic, 9 were white, non-Hispanic, and 1 Native American/Alaskan native. 1 was hearing impaired, and 3 were mobility impaired. They included ESL students, low income workers, homemakers who are entering the work force, or displaced workers seeking new employment opportunities. 


\section{Treatments}

Lab Experience $\left(\mathbf{X}_{\mathbf{L}}\right)$. The test subjects participated in a hands-on exercise in a classroom laboratory under the guidance of peer mentors. The exercise was composed of three units: (1) hand washing, (2) preparation of wet mounts and use of a compound light microscope and (3) the use of the microscope to view prepared slides with the oil immersion lenses.

STEM Video $\left(\mathbf{X}_{\mathbf{V}}\right)$. The YouTube video: Beyond the Lab: Careers in Science where six international students, with different interests in STEM, discussed the careers that continue to motivate them post-graduation.

\section{Instruments}

Interview Protocol. This section involved all GED student participants being interviewed prior to and after the lab experience and the video. In the Pre-treatment interview, I asked the following five open-ended questions:

1. What are the major reasons that you have enrolled in a GED program?

2. What are your plans after you obtain your GED?

3. What careers interest you that will be possible for you after you obtain your GED?

4. What do you see yourself doing in 5 years?

5. Are you interested in science or technology?

The following Post-Treatment questions were used to determine changes in confidence or interest in STEM or STEM careers: 
1. What did you think of the video? Did the video change how you feel about science or technology careers? Why or why not?

2. Do you see a greater relationship between science and everyday life?

3. There were three laboratory exercises in this experience. What can you tell me about them?

4. What parts did you like? What parts didn't you like?

5. Was it helpful having the CLA students there as mentors?

6. What else interested you? Are there other exercises you would like to try?

7. Can you tell me if you can see a change in your confidence in science or in technical careers after this exercise?

Peer-Mentor Focus Group Debriefing. I asked five open-ended questions to the CLA student mentors about their experiences and insights about their interaction with the GED students. This instrument was tested for reliability and adjusted during a pilot involving twenty allied health students:

1. What did you think of the exercises with the GED students?

2. Did you think the GED students benefited from the exercises? Why or why not?

3. Do you believe your involvement added to their interest? Why or Why not?

4. Do you believe that you benefited from this experience? Why or why not?

5. What changes would you make to this experience? 


\section{$\underline{\text { Results }}$}

\section{Pre-Treatment Interviews (Formal Study)}

15 Pre-interviews were conducted prior to the STEM video and laboratory experience. Five open-ended questions were asked about the GED students' immediate plans, their future plans, and their interest in STEM:

All of the GED interviews took place in a small office in the GED classroom area. The GED class is held in room 240 in the OIT building on the Harmony campus. The preinterviews lasted 7 to 10 minutes each and took place over the course of two weeks prior to viewing the video. Because of the sporadic nature of student attendance in the GED classroom, there were different people available each day to be interviewed.

\begin{tabular}{|l|c|c|c|}
\hline Table 1: Major reasons given to enroll in a GED program \\
\hline Participant Response & Number & Total & Percentage \\
\hline Finish GED, start college & 6 & $6 / 15$ & $40 \%$ \\
\hline Work on basic skills, refresher & 4 & $4 / 15$ & $26.67 \%$ \\
\hline Finish GED, better job & 4 & $4 / 15$ & $26.67 \%$ \\
\hline Be an example to child & 1 & $1 / 15$ & $6.67 \%$ \\
\hline
\end{tabular}

The breakdown of the major reasons for the students to pursue their GED shows that almost half intend to go on to college, in most cases, to community college [Table 1]. The remainder chiefly intends to pursue a better (non-minimum wage) job or improve reading and writing skills. The most conspicuous finding from the Pre-Treatment interviews is that proportionally more of the female GED students had clearly visualized plans (RN, fitness instructor, Veterinarian, CLA, CNA and architect) than the male students (Child 
Psychologist, military). Only 2 of the female GED students were uncertain about choices, whereas most of the male students had difficulty narrowing down their options [Table 2].

\begin{tabular}{|l|c|c|c|}
\hline \multicolumn{5}{|l|}{ Table 2: Post GED Plans (Separated by Gender) } \\
\hline Female Participant Response & Number & Total & Percentage \\
\hline Go to College & 6 & $6 / 8$ & $75 \%$ \\
\hline Not Sure, exploring options & 2 & $2 / 8$ & $25 \%$ \\
\hline Male Participant Response & Number & Total & Percentage \\
\hline Go to College & 1 & $1 / 7$ & $71.4 \%$ \\
\hline Join Military & 1 & $1 / 7$ & $14.3 \%$ \\
\hline Not Sure, exploring options & 5 & $5 / 7$ & $14.3 \%$ \\
\hline
\end{tabular}

The students with the most defined career goals also had the most interest in STEM. Also, the students who identified STEM careers as goals intended to attend community college at a higher rate than those who did not plan STEM careers. The students with the clearest goals also made the most eye contact, and sat the straightest. When asked about what their lives would look like in 5 years, the students with the clearest goals also had the most optimistic outlook. The students with vague plans tended to slouch and made the least eye contact. Their responses also had the least animation: "I'm getting my GED, and then I'm going to look for a better job," as if they were saying, "I get asked this all the time...sigh." I was almost expecting their eyes to roll. One male student, hanging his head and looking down, said he was going to enroll in culinary school based on a commercial he had seen. When prompted about possible interest in science and technology, however, he abruptly declared his love for computers and technology, sat up and beamed. Three other male students mentioned vague interest in "something in business, maybe my own, I don't know." The students without a clear vision could not 
plan 5 years into the future. Concomitantly, the students who had undefined careers to pursue, also claimed the least interest in science, or found it intimidating [Table 3].

\begin{tabular}{|c|c|c|c|c|}
\hline Female Participant Response & STEM & Number & Total & Percent \\
\hline $\begin{array}{l}\text { "Yes. I want to work with children } \\
\text { and help people (Pediatric RN)." } \\
\text { "Yes, I want to work in a health } \\
\text { career (CLA, CNA)." } \\
\text { "Yes, I want to work with the } \\
\text { elderly; (learning science) would } \\
\text { help my practice." }\end{array}$ & Yes & 4 & $4 / 8$ & $50 \%$ \\
\hline $\begin{array}{l}\text { "Yes. I want to work with animals, } \\
\text { those that have been mistreated. I } \\
\text { could take the CLA program to see } \\
\text { if it interests me" (Veterinarian). }\end{array}$ & Yes & 1 & $1 / 8$ & $12.5 \%$ \\
\hline $\begin{array}{l}\text { "Yes, I am interested in the human } \\
\text { body, including nutrition and } \\
\text { fitness" (Fitness Instructor) }\end{array}$ & Yes & 1 & $1 / 8$ & $12.5 \%$ \\
\hline "Not sure, exploring options." & No & 1 & $1 / 8$ & $12.5 \%$ \\
\hline "No. Science is intimidating to me & No & 1 & $1 / 8$ & $12.5 \%$ \\
\hline Male Participant Response & STEM & Number & Total & Percent \\
\hline $\begin{array}{l}\text { "Yes. Electronics would be } \\
\text { interesting, I like computers." } \\
\text { "Yes. I love technology, I see } \\
\text { myself as a computer nerd." }\end{array}$ & Yes & 2 & $2 / 7$ & $28 \%$ \\
\hline "Cool; I want to know more." & Yes & 1 & $1 / 7$ & $14 \%$ \\
\hline $\begin{array}{l}\text { "I'm not sure, what would I choose } \\
\text { to do?" } \\
\text { "Not sure, exploring options." } \\
\text { "Not really." }\end{array}$ & No & 4 & $4 / 7$ & $57 \%$ \\
\hline
\end{tabular}

\section{Post-Treatment Interviews (Formal Study)}

The STEM video was shown in the GED classroom after all the pre-interviews were completed. The classroom laboratory experience took place the next day, in room 
360, in the Clackamas Community College Health Sciences building, adjacent to the building where the GED class was held. Both buildings are on the Harmony campus.

Because the emphasis of the treatment was to promote situational interest in STEM, and the GED students were physically involved with their experience as well as being socially involved with their mentors, the post-treatment interviews were centered on the video and the three laboratory exercises.

After the GED students' experience, I asked eight open-ended questions about the student's likes and dislikes about the treatments and if they felt differently about science. As a whole, the demeanor of each student altered after the treatment. This was especially apparent in the students who were most unsure about their career plans. Whereas before I was getting standard answers, such as "I want to get my GED to get a better job/go back to school" with poor eye contact, little inflection and less willingness to elaborate, I was now hearing more about what they would like to do, or changes they wanted to make, with lots of eye contact and more expressive gestures. This was most pronounced in the students, both male and female, who had been uncertain about career goals. Many of the comments about the video included their increased sense of awareness of all the things that were part of science, and the connections to everyday life. Among the comments that were made about the video was that it expanded their awareness of the different things that could be called "science", that many fields of application were available, and that people really enjoy what they do and how it involves STEM careers. One said, "I liked the video; I could see how each person made the connection between what they liked about science and the career choices they made." Most of the students 
were happy with the content of the video, though a couple indicated they weren't interested in the personal experiences and expected to see an actual scientific procedure.

Only one student claimed that the video did not change her interest in STEM:

“The video didn't change how I feel about science and technology, but I will keep an open mind. I learned a lot about how science impacts our lives.” Two of the students reported that prior to the video they felt ambiguous about participating in the laboratory experience, but that the video made them more interested in attending. In the questions regarding the laboratory experience, all the interviewees could describe the three exercises in detail and could point out the features from each exercise that had impressed them.

From the hand washing exercise, they described where on their hands they had seen bacteria before and after the instructions and what actions they believed made the most difference. A couple of the students described how they continued to wash their hands and recheck under the black light to see more differences, trying this technique and that technique. This type of inquiry was more popular with the male students. "I thought I knew how to clean my hands! I had to wash them three times and there were still spots of bacteria!"

For the wet mount station, some of the students said their mentors had added stains to bring out certain features in their cheek cells, and asked about the cell structures they had seen. Most of the students explained how they were surprised to see so many types of cells, after looking at the blood films under the microscope. One student remarked, "I had no idea what I looked like on the inside." Another said, "I was surprised that we could look at how the body works in just an everyday exercise!" Most of the 
students preferred the blood smear exercise over the wet mount or hands washing exercises, but none of the exercises were disliked [Table 4]. One stated, "I was really interested in what we did; we could see what was on our hands, what the inside of our cheeks look like, and what the blood in our bodies looks like."

When asked about the CLA peer mentors, the students all reported that they were

\begin{tabular}{|l|l|c|c|}
\hline \multicolumn{4}{|l|}{ Table 4: What exercises did you like the best? } \\
\hline Participant Response & Number & Total & Percentage \\
\hline I liked the hand washing best. & 1 & $1 / 15$ & $7 \%$ \\
\hline I liked the cheek cells best & 1 & $1 / 15$ & $7 \%$ \\
\hline I liked looking at the blood smears best & 11 & $11 / 15$ & $73 \%$ \\
\hline I liked them all equally & 2 & $2 / 15$ & $13 \%$ \\
\hline What exercises did you like the least? & Number & Total & Percentage \\
\hline Participant Response & 1 & $1 / 15$ & $7 \%$ \\
\hline I liked the hand washing the least & 1 & $1 / 15$ & $7 \%$ \\
\hline I liked the cheek cells the least & 0 & $0 / 15$ & $0 \%$ \\
\hline I liked looking at the blood smears the least & 13 & $13 / 15$ & $86 \%$ \\
\hline I didn't dislike any & & & \\
\hline
\end{tabular}

glad they were there to assist them in the unfamiliar classroom laboratory and guide them through the three exercises. The GED students uniformly considered their mentors supportive. Their mentors not only had provided insight about the specific exercises, but also about the training the CLA students were getting in a science career. The CLA students proved to be good resources for their questions, and made the experience more enjoyable for the GED students. The students indicated that the CLA's positive presence added to the educational aspect. As one student remarked, "They made learning fun."

Other students spoke about the social aspects of having the CLA students present. One said, "They were friendly and patient while I did the exercises." Another mentioned, "I enjoyed talking with them." At the end of the exercises, 5 of the 15 GED students were 
found asking about prerequisites for the CLA program and how often it is offered at the college. As I had mentioned previously, most of the students were more animated and conversational after the exercise, and expressed interest in participating in more science experiences. Overall, they wanted to come back and have more time with the microscopes, trying different dyes and seeing more materials that we might have access to. I was asked about opportunities to investigate plants and life cycles, plus more health topics [Table 5].

\section{Table 5: Increased Interest in Science GED Participant Response}

Yes: "I would like to spend more time with the more microscopes, try different dyes to see more features."

Yes: "I would like to see things with more shapes and sizes."

Yes: "I would like to do some exercises with life cycles or plants."

Yes: "I would like to see about exercises with energy and chemical changes."

Yes: "Could we do another exercise about Recycling?"

Yes: "I would like to know about more Health subjects."

Yes: "It would be interesting, see what cancer looks like, how to do more tests"

I found that the majority of the GED students reported a positive change in confidence about STEM after this experience, especially in their willingness to take more science classes. Many of them remarked that doing the hands-on exercises made science more personable and less intimidating. One student said, "I can see myself in a lab, moving around, doing things. This experience was inspirational to me" [Table 6].

When comparing the pre- and post-treatment interest data, the most marked difference was in the male GED students. Initially, only 2 of the 7 had definite career goals, one of which was STEM related. The remaining 5 male GED students did not have definite career goals, with 4 showing no interest in STEM, and 1 with mild interest. After the 
Table 6: Increased Confidence in Science/Technology

GED Participant Response

Yes: "I feel more comfortable thinking about cells and bacteria and stuff."

Yes: "I would enjoy doing research in a laboratory."

Yes: "I would like to start taking science classes, learn more about stuff."

Yes: "I can do this!"

Yes: "I am more excited about being in a science class, learning how to do things."

Yes: "I can see myself in a lab, moving around, doing things. This experience was inspirational to me."

Yes: "Doing this made science more personable and less intimidating to me."

treatment, 6 exhibited interest in pursuing STEM education or employment; the lone male participant not interested in pursuing further education confirmed his intention of joining the military. The female GED students' interest remained unchanged, but in view of the fact that 6 of 8 had already had definite plans to enter STEM strong careers, both the male and female students showed equivalent interest in STEM post-treatment. There was no decrease in interest in any of the students who had shown interest pre-treatment [Figure 2].

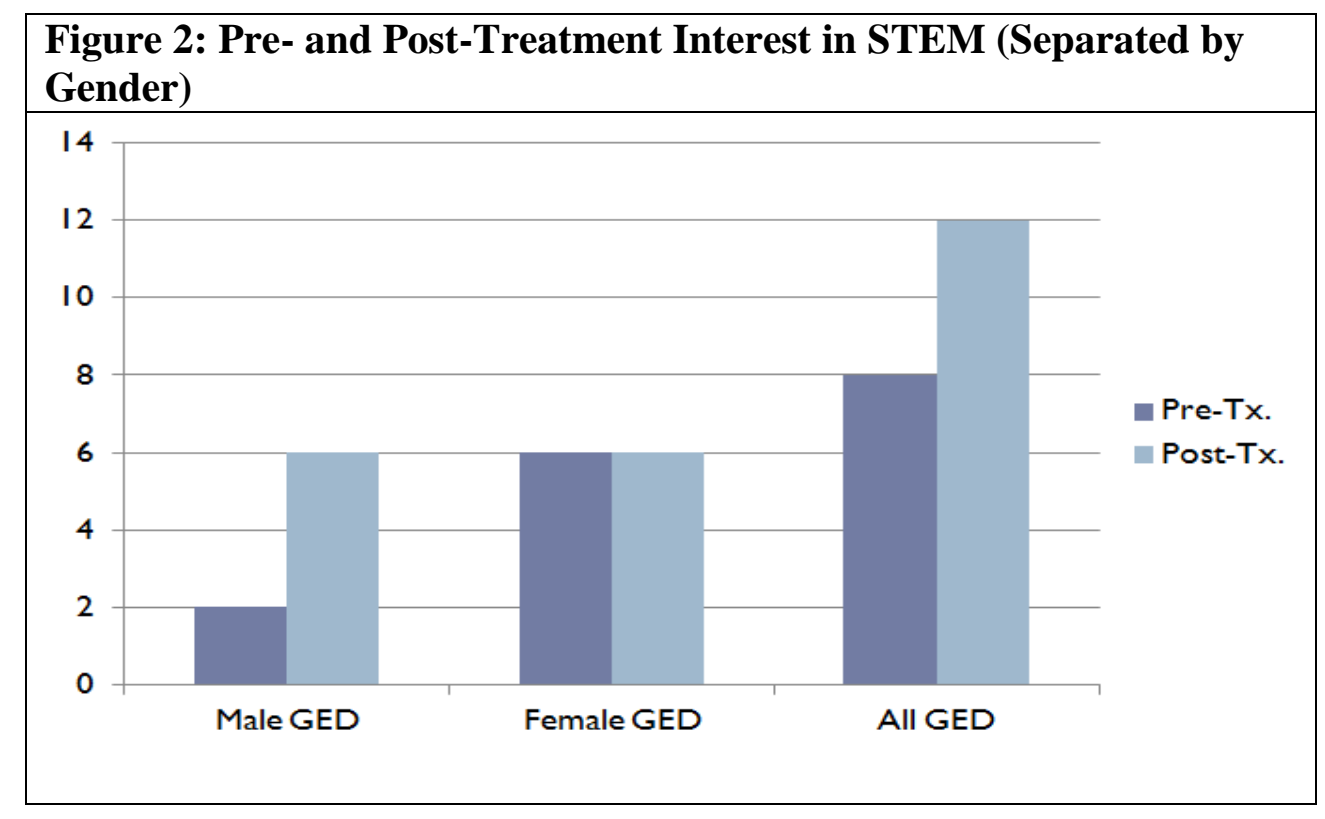




\title{
Peer Mentor Debriefing (Formal Study)
}

\author{
Table 7. Formal Study: Peer Mentor Debriefing \\ 1. What did you think of the exercises with the GED students? \\ "I thought they were simple enough for them to do." \\ "They were timely and interesting. I think the students enjoyed them. " \\ "Yes. The exercises were clean and simple for them to do." \\ "I think they were appropriately designed for the level of education they already had." \\ "The blood smears were popular."
}

\section{Did you think the GED students benefited from the exercises? Why or why not?}

"Yes, they get to learn about all the cool stuff we get to do all year. I had two very enthusiastic students. I think they learned a lot and had fun."

"Yes, the hand washing exposed them to the idea of germs. The scopes introduced them to science; just being at a college in a lab was beneficial for them to get the exposure.'

"Yes. I think the students get a lot of benefit from the exercises because it shows them they can do "lab" work."

"The exercises were interesting and served to motivate and excite them."

"The students appeared interested and had lots of questions. It seemed beneficial because it generated interest in lab work."

\section{Do you believe your involvement added to their interest? Why or Why not?}

"Yes. I love looking at blood; it excites me. When a teacher or mentor is excited about something, it usually gets the students excited too."

"Yes. I think it was helpful to have someone walk them through and answer questions."

'Yes. I feel like my involvement added a lot because I told them a little about my history, which was not even close to the medical profession. I tried not to use technical terms so not to confuse them, but I told them a few so they had "something to bring home" in their brain."

"Yes. I think it did because it is more interesting to converse then to just read and describe a document. Being shown how to perform an exercise is the way to go."

"Yes. Our involvement seemed helpful. We could talk about our personal experience in the lab."

\section{Do you believe that you benefited from this experience? Why or why not?}

"Yes, I have always enjoyed helping others, and this just reminds me again that I do. Also, it gives me more respect for my teachers."

"Yes. It allowed me to briefly share my experience in school, and explain how they could achieve the same."

"Yes, I really like helping people, so I enjoyed the experience very much. I realized how much I know and that I was somewhat in their position, by not knowing what I was looking at. The more I learned about cells though, the more I can automatically identify cells and equipment." "Yes. I gained valuable experience."

"Yes. I think I gained insight into how lab work appears to others - somewhat daunting. Something I need to keep in mind in healthcare."

\section{What changes would you make to this experience?}

"I think we should have shown them a blood draw and explained the process. I think they would have enjoyed that."

"Maybe allow them to palpate veins? Show them how to take blood pressures?"

"Make more time for another mentoring session like this. "

"I would give them more time to explore." 
At the debriefing held immediately after the laboratory exercises, I asked all the CLA peer mentors to each write an assessment of their experience [Table 7]. Using the results from these assessments, not only were the peer mentors able to see the increased situational interest by the GED students, but they themselves developed greater confidence as CLA's under these conditions. They showed self-confidence, through answering questions and explaining concepts to others that which they have been learning over the course of their training. Additionally, it was good practice for them, being in placed in situations that can arise as they are employed in their field. 


\section{Discussion:}

Because the peer-to-peer setting provided greater familiarity and informality than a teacher-student setting, we found that the GED students were able to ask questions in a no-personal-risk environment. This supports Turner \& Patrick (2004) in that this experience provided autonomy, social relatedness and competence, without competition. This student-centered experience attempted to overcome the GED students' perception that they are "unsuccessful" and not competent in science or STEM related studies. As suggested by Glowinski \& Bayrhuber (2011), the intent was to develop their motivation through a supportive social context. Additionally, in the choice of video and the exercises developed for this study, the GED students were shown relevance of STEM to their everyday lives, so that they would be more receptive and engaged in the content.

In the post-treatment interviews, nearly all of the students said they enjoyed the video and saw how the video made the connection between science and everyday life for them. Many of the comments about the video included their increased sense of awareness of all the things that were part of science, and its connection to everyday life. Among the comments was that the video expanded their awareness of what is called "science," and also that people can enjoy careers in a variety of STEM professions. Additionally, two students reported that they were unsure about attending the laboratory experience until they saw the video. After seeing the video, they decided to participate in the laboratory exercises because the video was more interesting than they had expected.

As was noted in this study, the GED students who were not motivated to pursue definite education or career goals prior to this intervention demonstrated a defeatist attitude. This is consistent with Peetz, Wilson \& Strahan's findings (2009) that if students 
are persuaded to consider graduation and their life goals imminent to their present state, they show higher levels of academic motivation than those who felt graduation as remote. During the pre-treatment interviews, the GED students without career focus showed poor posture and were less animated than the GED students who already had clear education and career goals. They did not have any immediate plans for themselves after they had obtained their GED and viewed career success as a vague and distant goal. These same students demonstrated, in the post-treatment interviews, a gain in motivation through their improved posture, increased animation, increased engagement with the interviewer, and enhanced eye contact. They expressed excitement about their education and career prospects similar to the students who had clear goals (veterinarian, registered nurse, architect) prior to the treatment. They also indicated they felt confident doing science related activities and felt more likely to pursue STEM classes. By increasing the social aspects of learning there was a significant increase of engagement; as one GED student remarked, "(the CLA students) made learning fun” (Tinto, 1998).

This experience proved to be equally beneficial to the CLA students, in terms of how they were challenged to use their new knowledge and skills. This experience successfully improved their self-efficacy. The change in how they perceived themselves (Mastery) "I realized how much I know and that I had been in their position, not knowing what I was looking at", their students' feedback (Verbal), and the GED students' actions (Vicarious) "I think the students get a lot of benefit from the exercises because it shows them they can do 'lab' work." and from their own excitement (Psychological) "when a teacher or mentor is excited about something, it usually gets the students excited too." 
were evident from their assessments of the experience (Bandura, 1997). The increase in self-efficacy by the CLA students also increased the GED students' learning. This supports the findings of DeChenne et al. (2012).

Upon the completion of this experience, the data collected in this study indicate that the GED students who had been previously undecided about their educational opportunities and career choices were aided by this type of educational intervention. As was noted in the post-treatment interviews, one student, who had previously said, "I'm not sure, what would I choose to do?" was next saying, "I would like to start taking science classes, learn more about stuff." And as another stated, "I would enjoy doing research in a laboratory."

\section{Limitations of Study}

The limits of the study were evident after completing the pilot study in 2012 . The format was determined by (1) the number of students enrolled in the CLA program during the year being studied; (2) the GED classes within walking distance of the oncampus laboratory; (3) the point during the 9-month CLA program the students had reached an appropriate level of training to act as peer mentors; (4) the size of the GED class at the time the study was performed; and (5) the need for a longitudinal study to be performed to determine if each GED student who participated in this study successfully obtained his or her GED, and what number enrolled in higher education.

\section{Conclusion:}

In reviewing the research question, "Do adult learners in a GED/ABE program increase their interest in STEM as a result of a video/laboratory experience presented by 
peers?", the preliminary results of this study suggest that interest in STEM education and STEM careers can be generated with peer mentored learning, using a hands-on model. This supports the first hypothesis: "By providing a positive and supportive laboratory experience, through the use of peer mentors, GED students will gain confidence in science-related activities and seek enrollment in health careers." This model warrants further research into developing interventions to promote STEM interests, such as the use of hands-on exercises, peer mentors, and cohort programs.

In regards to the second research question, "Does acting as peer mentors for adult learners in a laboratory experience increase self-efficacy in CLA students?" their increased levels of self-efficacy, as seen in the self-assessment, followed closely to Bandura's four sources of self-efficacy (1997): Mastery (seeing the change in their own knowledge during their course of study), Verbal (the feedback they received), Vicarious (seeing their protégés process their learning, and Psychological (seeing their own excitement reflected back). This supports the second hypothesis, "By acting as peer mentors, the CLA students will improve their self-efficacy through the opportunity to demonstrate their knowledge."

I would like to include the GED students in more activities with the CLA students; how their pulse is related to how we measure blood pressure, or how the types of bacteria found on the skin differ from those found in the nasal passages. Repeated events of situational interest have been observed to lead to personal interest (Mitchell \& Gilson, 1997). As one of my students suggested, our program would benefit from additional opportunities to mentor. Since the CLA students are required to make 
presentations of the research they do regarding specific diseases, they could do encore presentations for the benefit of the GED classes as well.

A longitudinal study would have to be performed to determine if each GED student who participated in this study successfully obtained his or her GED, and what number enrolled in higher education. It would be worthwhile to determine if by repeating this GED: CLA experience every March/April with each progressive CLA class we could see if the GED participants not only persisted in their education, but if they remained interested in STEM education specifically. Gathering this data would necessitate getting serial updates from all subjects involved. It has been suggested that a specified Face Book account be set up to gather this data. Also, doing an ANOVA (analysis of variance) with successive classes would help determine if there are significant differences in composition between the GED classes analyzed, especially in this year's finding that the female GED participants were focused on their future goals at a higher rate than their male counterparts.

\section{$\underline{\text { Recommendations }}$}

As Berbatis suggested in his study (2008) that specific competencies should be taught in modular form, I recommend that each subject (life sciences, physical science, and mathematics) is taught in a month-long block, so that students can progress through their studies and gain a sense of success. Scheduling an appropriate STEM experience at the end of each module would combine situational interest with the GED students' sense of accomplishment. This could potentially generate interest in specific educational and career goals. For example, integrated with a mathematics module, the GED students could look forward to a session in the computer lab with peer mentors, creating models 
and altering these images using mathematical relationships. The computer science students would also benefit from the peer mentoring experience.

By widening the scope of this treatment with STEM experiences other than health science, it would be interesting to see what STEM education/career choices are the most popular after this type of intervention, and which prove to be the most successful. I believe it would be efficacious for other teachers in life sciences, physical science, and mathematics to use this model to provide similar peer mentored experiences. This approach could help rectify these problems:

- There are fewer students pursuing STEM educations leading to STEM careers;

- There are not enough STEM workers to meet the increasing demands of technology;

- Society is becoming more technologically advanced, and ordinary citizens must be able to make increasingly sophisticated science-based decisions affecting their lives including energy usage and threats to the environment (Rudavina et al., 2012);

- There is an overwhelming need for programs that empower adults without high school diplomas to obtain their GED and develop persistence in obtaining higher education (Yan, 2002, Hyslop 2010).

By promoting STEM through CCC, we could see more students from the ClackamasMultnomah area pursue STEM education through either completing an available technical program or pursuing a university degree in a STEM field. 


\section{$\underline{\text { References }}$}

Ashmore, Rhea A. (1987). The Adult Learner: Implications and Activities for Implementation. National Conference of the Western College Reading and Learning Association. Albuquerque, NM April

Balfanz, R. et al. Council of Chief State School Offices (CCSSO), America's Promise Alliance. (2013). High school graduation: State policies driving transparencies and success. Retrieved from website: http://www.ccsso.org/Documents/2013/CCSSO_High_School_Graduation_Polici es_2013.pdf

Bandura, A. (1986). Social foundations of thought and action: a social cognitive theory. $\left(1^{\text {st }}\right.$ ed.). Englewood Cliffs, NJ: Prentice-Hall, Inc.

Bandura, A. (1997). Self-efficacy: the exercise of control. New York, NY: W. H. Freeman and Company.

Barbatis, P. (2008, March). Perceptions of underprepared community college students regarding their educational achievement: Preliminary analysis of a pilot study. Online Submission, Paper accepted for presentation at the Annual Meeting of the American Educational Research Association (2008) Sig: mentorship and mentoring practices, New York, NY. Retrieved from http://www.eric.ed.gov/PDFS/ED500812.pdf

Becker Patterson, M., Song, W., \& Zhang, J. American Council on Education, (2009). Ged candidates and their postsecondary educational outcomes: A pilot study. ged testing service[r] research studies, 2009-5. Retrieved from GED Testing Service website: http://www.GEDtest.org

DeChenne, S. E., Enochs, L. G. \& Needham, M. (2012). Science, technology, engineering, and mathematics graduate teaching assistants teaching self-efficacy. Journal of the Scholarship of Teaching and Learning, 12(4), 102-123. Retrieved from http://josotl.indiana.edu

Department of Business, Innovation and Skills (2010) "Attitudes to science: survey of 14-16 year olds." London, UK.

Domene, J., Socholotiuk, K., \& Woitowicz, L. (2011). Academic motivation in postsecondary students: Effects of career outcome expectations and type of aspiration. Canadian Journal of Science Education, 34(1), 99-127.

Driver, R. (1989) Students' conceptions and the learning of science: a constructionist view. International Journal of Science Education, (11), 481-490. 
Glynn, S. M., Brickman, P., Armstrong, N., \& Taasoobshirazi, G. (2011). Science Motivation Questionnaire II: Validation with science majors and nonscience majors. Journal of Research in Science Teaching, 48, 1159-1176.

Goff, L. (2011). Evaluating the outcomes of a peer-mentoring program for students transitioning to postsecondary education. Canadian Journal for the Scholarship of Teaching and Learning, 2(2), doi: http://dx.doi.org/10.5206/cjsotl-rcacea.2011.2.2

Greenes, C., Wolfe, S., Weight, S., Cavanagh, M., \& Zehring, J. (n.d.). Prime the pipeline project $\left(\mathrm{p}^{3}\right)$ : Putting knowledge to work dynamic science learning environment for k-12 teachers. (2011). Contemporary Issues in Technology and Teacher Education (CITE Journal), 11(1), 21-46. ERIC: EJ930140

Hidi, S. \& Harakiewicz, J.M. (2000). Motivating the academically unmotivated: A critical issue of the $21^{\text {st }}$ century. Review of Educational Research, 70(2), 1151179.

Hyslop, A. (2010). Cte's role in science, technology, engineering and mathematics. Association for Career and Technical Education (ACTE), Alexandra, VA

Jenkins, D., Zeidenberg, M., \& Kienzl, G. (2009). Education outcomes of I-BEST: Washington state community and technical college system. Unpublished manuscript, Community College Research Center (CCRC), Teachers College, Columbia University, New York City, NY.

Mamlok-Naaman, R. (n.d.). How can we motivate high school students to study science? (2011). Science Education International, 22(1), 5-17. ERIC: EJ941648

Mitchell, M. \& Gilson, J. (1997, March). Louise Cherry Wilkinson (Chair). Interest and anxiety in mathematics. Paper presented at the Annual Meeting of the American Educational Research Association; talking together in educational research and practice, Chicago, IL.

Palmer, D. H. (2009). Student interest generated during an inquiry skills lesson. Journal of Research in Science Teaching, 46(2), 147-165.

Peetz, J., Wilson, A. E. \& Strahan, E. J. (2009). So far away: the role of subjective temporal distance to future goals in motivation and behavior. Social Cognition, 27(4), 475-495. doi: 10.1521/soco.2009.27.4.475.

Rannikmae, M., Teppo, M., \& Holbrook, J. (2010). Popularity and relevance of science education literacy: Using a context-based approach. Science Education International, 21(2), 116-125. ERIC: EJ89066 
Rukavina, S., Zuvic-Butorac, M., Ledic, J., Milotic, B., \& Jurdana-Sepic, R. (n.d.). Developing positive attitude towards science and mathematics through motivational classroom experiences. (2012). Science Education International, 23(1), 6-19. ERIC: EJ975543

Tinto, V. (1995). Learning communities, collaborative learning, and the pedagogy of educational citizenship. AAHE Bulletin, 47(7), 11-13.

Turner, J. C. \& Patrick, H. (2004). Motivational influences on student participation in classroom learning activities. Teacher College Record, Columbia University, 106(9), 1759-1785.

Van Horn, B. L. \& Kassab, C. Pennsylvania General Assembly, Center for Rural Pennsylvania. (2011). An analysis of rural and urban pennsylvania adults taking, completing and passing the ged Retrieved from website: $\underline{\text { www.rural.palegislature.us }}$

Whiting, S., Guglielmino, L. M. \& Burrichter, A. W. (1988). Adult Development. What do Teachers of Adults Need to Know? Florida Atlantic University, Adult Education Division. Boca Raton, FL

Wolters, C. A. \& Pintrich, P. R. (1998). Contextural differences in student motivation and self-regulated learning in mathematics, english and social studies classrooms. International Science, 26(1-2), 27-47. 


\section{$\underline{\text { Appendices }}$}

\section{A. Pilot Study: Pre-Treatment Questionnaire Results}

1. Technology Section: Which of these have you used? Check all that apply.

\begin{tabular}{|l|l|l|l|l|l|}
\hline Item & Number & Percent & Item & Number & Percent \\
\hline Cell Phone & 10 & $100 \%$ & I-Pod & 7 & $70 \%$ \\
\hline Digital Camera & 9 & $90 \%$ & Movie Camera & 4 & $40 \%$ \\
\hline CD Player & 8 & $80 \%$ & DVD & 9 & $90 \%$ \\
\hline $\begin{array}{l}\text { Word } \\
\text { Processing }\end{array}$ & 3 & $30 \%$ & Nintendo & 5 & $50 \%$ \\
\hline Wii & 6 & $60 \%$ & X-Box & 5 & $50 \%$ \\
\hline $\begin{array}{l}\text { Scientific } \\
\text { Calculator }\end{array}$ & 5 & $50 \%$ & Internet & 9 & $90 \%$ \\
\hline Email & 8 & $80 \%$ & Graphing Calculator & 1 & $10 \%$ \\
\hline PowerPoint & 3 & $30 \%$ & Skype & 5 & $50 \%$ \\
\hline MP3 Player & 7 & $70 \%$ & EXCEL Spreadsheet & 3 & $30 \%$ \\
\hline VCR & 8 & $80 \%$ & Text Messaging & 8 & $80 \%$ \\
\hline
\end{tabular}

2. Laboratory Section: Which of these have you used? Check all that apply.

\begin{tabular}{|l|l|l|l|l|l|}
\hline Item & Number & Percent & Item & Number & Percent \\
\hline Microscope & 6 & $60 \%$ & Scale & 6 & $60 \%$ \\
\hline Centrifuge & 1 & $10 \%$ & Calipers & 2 & $20 \%$ \\
\hline Thermometer & 4 & $40 \%$ & Telescope & 6 & $60 \%$ \\
\hline Metric Rulers & 5 & $50 \%$ & Petri Dishes & 2 & $20 \%$ \\
\hline Beakers & 4 & $40 \%$ & Safety Goggles & 7 & $70 \%$ \\
\hline Glass Slides & 3 & $30 \%$ & Test Tubes & 4 & $40 \%$ \\
\hline Pipettes & 1 & $10 \%$ & Hot Plate & 1 & $10 \%$ \\
\hline Bunsen Burner & 3 & $30 \%$ & Chemicals (Acids, etc.) & 6 & $60 \%$ \\
\hline
\end{tabular}

3. Everyday Section: Which of these have you used? Check all that apply.

\begin{tabular}{|l|l|l|l|l|l|}
\hline Item & Number & Percent & Item & Number & Percent. \\
\hline Microwave & 9 & $90 \%$ & Bread Machine & 8 & $80 \%$ \\
\hline Food Processor & 8 & $80 \%$ & Ice Maker & 7 & $70 \%$ \\
\hline Air Conditioner & 6 & $60 \%$ & Microphone & 7 & $70 \%$ \\
\hline Air Compressor & 4 & $40 \%$ & Lathe & 2 & $20 \%$ \\
\hline Sander & 6 & $60 \%$ & Grinder & 4 & $40 \%$ \\
\hline
\end{tabular}


4. Do you like any of these? Check all that apply.

\begin{tabular}{|l|l|l|l|l|l|}
\hline Item & Number & Percent & Item & Number & Percent \\
\hline Sudoku & 2 & $20 \%$ & Crosswords & 6 & $60 \%$ \\
\hline Brain Busters & 5 & $50 \%$ & Origami & 2 & $20 \%$ \\
\hline Logic Puzzles & 3 & $30 \%$ & Sim City & 1 & $10 \%$ \\
\hline
\end{tabular}

5. Which of these math/science courses have you taken? Check all that apply.

\begin{tabular}{|l|l|l|l|l|l|}
\hline Class & Number & Percent & Item & Number & Percent \\
\hline Algebra I & 3 & $30 \%$ & Algebra II & 0 & $0 \%$ \\
\hline Geometry & 3 & $30 \%$ & Biology & 1 & $10 \%$ \\
\hline Chemistry & 1 & $10 \%$ & None & 1 & $10 \%$ \\
\hline
\end{tabular}

6. What are your plans once you take your GED?

\begin{tabular}{|l|l|l|l|l|l|}
\hline Career Goals & Number & Percent & Item & Number & Percent \\
\hline Not sure & 3 & $30 \%$ & Get a job or better job & 2 & $20 \%$ \\
\hline Take classes & 1 & $10 \%$ & Lab Tech & 1 & $10 \%$ \\
\hline Veterinary Tech & 1 & $10 \%$ & Criminal Justice & 1 & $10 \%$ \\
\hline $\begin{array}{l}\text { Early Childhood } \\
\text { Dev }\end{array}$ & 1 & $10 \%$ & & & \\
\hline
\end{tabular}

7. Have you applied to any colleges? If so, which ones? No (10/10) 


\section{B. Pilot Study: Pre-Treatment Survey Results}

1. When you think of "the sciences", what comes into your mind?

CSI (8/10); discovery (1/10); learning how things work, energy, work (1/10); cool things I don't know about, but would like to (1/10); laboratory, earth, plants (1/10); unknown $\underline{(1 / 10)}$

2. When you think of "scientists", what comes to mind? smart/intelligent people (4/10); people in white outfits (2/10); people who study elements and things to do with them (1/10); someone who discovers things (1/10); world discovery (1/10); doctor $(1 / 10)$

3. Do you think there are any careers that don't use science? Yes $\underline{4}$ No $\underline{4}$ I don't know $\underline{2}$

4. What do you think of the following statements about science?

Please rate from 0 to 5 , with $0=\mathrm{I}$ don't know, $1=$ strongly disagree, $2=$ Tend to disagree, $3=$ Neither agree or disagree, $4=$ tend to agree, $5=$ Strongly agree

\begin{tabular}{|c|c|c|c|c|c|c|}
\hline Positive Statement (Forward Scoring): & 0 & 1 & 2 & 3 & 4 & 5 \\
\hline I am amazed by the achievements of science & & & 1 & 2 & 1 & 6 \\
\hline $\begin{array}{l}\text { Science is such a big part of our lives we should } \\
\text { all take an interest }\end{array}$ & & 1 & & 1 & 3 & 5 \\
\hline $\begin{array}{l}\text { It is important to know about science in my daily } \\
\text { life }\end{array}$ & & 1 & & 4 & 2 & 3 \\
\hline I am curious about discoveries in science & 1 & & & 1 & 3 & 5 \\
\hline The science I learn is relevant to my life & 1 & & 1 & 4 & 3 & 1 \\
\hline $\begin{array}{l}\text { Understanding science will help me get a good } \\
\text { job }\end{array}$ & 2 & 2 & & 3 & 1 & 2 \\
\hline $\begin{array}{l}\text { I will use science problem-solving skills in my } \\
\text { career }\end{array}$ & 1 & & & 4 & 2 & 3 \\
\hline Average & $5 / 7$ & $4 / 7$ & $2 / 7$ & $19 / 7$ & $15 / 7$ & $25 / 7$ \\
\hline Score & 0.71 & 0.57 & 0.29 & 2.71 & 2.14 & 3.57 \\
\hline \multicolumn{7}{|l|}{ Negative Statement } \\
\hline $\begin{array}{l}\text { Science and technology are too specialized } \\
\text { for most people to understand }\end{array}$ & & & 3 & 5 & 3 & \\
\hline $\begin{array}{l}\text { I don't understand the point of all the science } \\
\text { being done today }\end{array}$ & 2 & & 4 & 4 & & \\
\hline Average: & $2 / 2$ & & $7 / 2$ & $9 / 2$ & $3 / 2$ & \\
\hline Negative Score & 1 & & 3.5 & 4.5 & 1.5 & \\
\hline Positive Score & 0.71 & 0.57 & 0.29 & 2.71 & 2.14 & 3.57 \\
\hline
\end{tabular}


5. Outside of school, where, if anywhere, have you heard or read about science in the last month?

\begin{tabular}{|l|c|c|}
\hline Sources: & $\#$ & $\%$ \\
\hline TV News & $6 / 10$ & 60 \\
\hline TV (other than news) & $5 / 10$ & 50 \\
\hline Newspapers & $4 / 10$ & 40 \\
\hline Internet & $5 / 10$ & 50 \\
\hline Magazines & $2 / 10$ & 20 \\
\hline Family/Friends & $2 / 10$ & 20 \\
\hline Movies & $4 / 10$ & 40 \\
\hline Radio & $1 / 10$ & 10 \\
\hline None of these & $1 / 10$ & 10 \\
\hline
\end{tabular}

(Percentages exceed 100\%; most participants recorded more than one choice)

6. Which, if any, of these places have you visited or attended in the last 12 months?

\begin{tabular}{|l|c|c|}
\hline Venues & $\#$ & $\%$ \\
\hline Theme Park & 1 & 10 \\
\hline Concert & 1 & 10 \\
\hline Sports Event & 3 & 30 \\
\hline Zoo & 5 & 50 \\
\hline OMSI & 6 & 60 \\
\hline Planetarium & 2 & 10 \\
\hline None of these & 1 & 10 \\
\hline
\end{tabular}

(Percentages exceed 100\%; most participants recorded more than one choice)

7. What job areas are you most interested in working, after GED/Additional schooling?

\begin{tabular}{|l|c|c|}
\hline Careers & $\#$ & $\%$ \\
\hline Medical / Health & 4 & $40 \%$ \\
\hline Teaching / Education & 1 & $10 \%$ \\
\hline Law / Legal occupations & 1 & $10 \%$ \\
\hline Business / Financial & 1 & $10 \%$ \\
\hline Humanities / Languages & 2 & $20 \%$ \\
\hline Veterinary/Animal Care & 1 & $10 \%$ \\
\hline Public Sector & 1 & $10 \%$ \\
\hline Social Work & 2 & $20 \%$ \\
\hline Administrative & 1 & $10 \%$ \\
\hline
\end{tabular}

(Percentages exceed 100\%; most participants recorded more than one choice) 


\section{Scoring of the Microbiology Laboratory Tour Video (Pilot):}

What did you think of the video choice about the Microbiology Laboratory? There are no right or wrong answers, we only want your opinion.

1. Please rate from 0 to 5 , with $0=\mathrm{I}$ don't know, $1=$ strongly disagree, $2=$ Tend to disagree, $3=$ Neither agree or disagree, $4=$ tend to agree, $5=$ Strongly agree

\begin{tabular}{|l|c|c|c|c|c|c|}
\hline Statement: & 0 & 1 & 2 & 3 & 4 & 5 \\
\hline I enjoyed watching the video & & & 2 & 2 & 3 & 3 \\
\hline I think I learned a lot from the video & & & 2 & 2 & 4 & 2 \\
\hline I thought the video was very interesting & & & 2 & 2 & 2 & 4 \\
\hline Average: & 0 & 0 & $6 / 3$ & $6 / 3$ & $9 / 3$ & $9 / 3$ \\
\hline Score: & 0 & 0 & 2.0 & 2.0 & 3.0 & 3.0 \\
\hline
\end{tabular}




\section{Pilot Study: Post-Treatment Survey Results}

1. Please rate from 0 to 5 , with $0=\mathrm{I}$ don't know, $1=$ strongly disagree, $2=$ Tend to disagree, $3=$ Neither agree or disagree, $4=$ tend to agree, $5=$ Strongly agree

\begin{tabular}{|l|c|c|c|c|c|c|}
\hline Statement & 0 & 1 & 2 & 3 & 4 & 5 \\
\hline After this exercise I felt pretty confident & 1 & & & 1 & 5 & 3 \\
\hline I am satisfied with how I did & & & & & 5 & 5 \\
\hline This exercise was fun to do & & & & & 4 & 6 \\
\hline I enjoyed doing this exercise & & & & 1 & 4 & 5 \\
\hline I think I learned a lot & & & & & 4 & 6 \\
\hline I thought it was very interesting & & & & 4 & 6 \\
\hline $\begin{array}{l}\text { Doing the exercise with the CLA students } \\
\text { made it more fun }\end{array}$ & & & & & 4 & 6 \\
\hline $\begin{array}{l}\text { Doing the exercise with the CLA students } \\
\text { helped me learn more }\end{array}$ & & 1 & & 1 & 2 & 6 \\
\hline $\begin{array}{l}\text { I would be interested in doing more of these } \\
\text { exercises }\end{array}$ & $1 / 9$ & $1 / 9$ & 0 & $3 / 9$ & $36 / 9$ & $49 / 9$ \\
\hline Average: & 0.11 & 0.11 & 0 & 0.33 & 4.0 & 5.44 \\
\hline Score: & & & & & \\
\hline
\end{tabular}

2. What would have made this exercise more beneficial to you? Nothing (4/10); spend more time (4/10); see more bacteria in action! (1/10); wasn't my idea of a career (1/10). 


\section{E. Student Participant Consent Forms, GED Student Demographics Form, E.1}

\section{Lighting the Fire: Exposure to Science Study GED Student Participant Consent Form}

You are invited to participate in a research study conducted by Patricia DeTurk from Portland State University, Center for Science Education. The researcher hopes to learn how exposure to a laboratory environment affects test scores in science and to measure preconceptions about science, science careers and the influence of science. This study is being conducted in partial fulfillment of the requirements for a master's degree under the supervision of Stephanie Wagner, MS, at Portland State University. You were selected as a possible participant in this study because you are currently enrolled in the GED program at Clackamas Community College.

If you decide to participate, you will be asked to fill out a questionnaire (15 questions total), take 4 surveys, watch one science video (approximately 15 minutes), participate in 2 audio-taped interviews (about 5-10 minutes each), and cooperate in three science activities (approximately 1-1/2 to 2 hours) while in the laboratory classroom 360 at the Harmony campus of Clackamas Community College, the entire project involving two separate days, one week apart. While participating in this study, it is possible that there may be some minimal risk to participants. You may show some squeamishness at the presence of blood (under the microscope) or from the smells associated with the clinical laboratory, or from the use of white coats, that may be associated with a doctor's office. Any participant showing any anxiety or distress from the exercise is immediately excused. If you need water or need to lie down, arrangements will be made immediately.

You will not receive any direct benefit from taking part in this study, but the study may help to increase knowledge which may help others in the future.

Any information that is obtained in connection with this study and that can be linked to you or identify you will be kept confidential as much as possible. However, confidentiality cannot be guaranteed in a group setting.

- Each student will be identified by a letter of the alphabet, assigned randomly.

- Student questionnaires will be administered as hard copies and not reproduced electronically.

- Records will be stored, including in audio from interviews, for three years after the completion of this study, in a locked cabinet in the Center for Science Education at Portland State University.

- All records will be transported by the researcher from Clackamas Community College to Portland State University in a locked briefcase. 
Your participation is voluntary. Participation or non-participation will not affect your grades and will not affect your relationship with PSU or CCC.

If you have any questions or concerns about your participation in this study, contact Patricia DeTurk at Clackamas Community College, Harmony Campus - 7738 S.E. Harmony Road, Milwaukie, Oregon 97222, or at her number, 360-448-8529. If you have concerns about your rights as a research subject, please contact Research and Strategic Partnerships, Market Center Building $6^{\text {th }}$ floor, Portland State University, (503) 725-4288.

Your signature indicates that you have read and understand the above information and agree to take part in this study. The researcher should provide you a copy of this form for your own records.

Signature

Print Name 
E. Student Participant Consent Forms, GED Student Demographics Form E.2

\section{GED Student Demographics Form}

The following demographic information is being collected on all participants.

Gender:

Male Female

Ethnicity:

Hispanic or Latino

Not Hispanic or Latino

Race:

American Indian or Alaska Native

Asian

Black or African American

Native Hawaiian or Pacific Islander

White

Disability Status:

__ Hearing Impaired

Visually Impaired

Mobility/Orthopedic Impairment

Other:

None 


\section{E. Student Participant Consent Forms, GED Student Demographics Form E.3 \\ Lighting the Fire: Exposure to Science Study CLA Mentor Participant Consent Form}

You are invited to participate in a research study conducted by Patricia DeTurk from Portland State University, Center for Science Education. The researcher hopes to learn how exposure to a laboratory environment affects test scores in science and to measure preconceptions about science, science careers and the influence of science. This study is being conducted in partial fulfillment of the requirements for a master's degree under the supervision of Stephanie Wagner, MS, at Portland State University. You were selected as a possible participant in this study because you are enrolled in the CLA program at Clackamas Community College.

If you decide to participate, you will be asked to fill out a questionnaire, provide mentorship to a GED student in three science activities (approximately 1-1/2 to 2 hours) while in the laboratory classroom 360 at the Harmony campus of Clackamas Community College, and be interviewed as part of a debriefing (audio-taped) focus group with your fellow CLA students. Your involvement will take place over 2 days. While participating in this study, it is possible that there may be some minimal risk to participants. A GED student may show some squeamishness at the presence of blood (under the microscope) or from the smells associated with the clinical laboratory, or from the use of white coats, that may be associated with a doctor's office. Any participant showing any anxiety or distress from the exercise is immediately excused. If anyone needs water or needs to lie down, arrangements will be made immediately.

You will not receive any direct benefit from taking part in this study, but the study may help to increase knowledge which may help others in the future.

Any information that is obtained in connection with this study and that can be linked to you or identify you will be kept confidential as much as possible. However, confidentiality cannot be guaranteed in a group setting.

- Each student will be identified by a letter of the alphabet, assigned randomly.

- Student questionnaires will be administered as hard copies and not reproduced electronically.

- Records will be stored, including in audio from interviews, for three years after the completion of this study, in a locked cabinet in the Center for Science Education at Portland State University.

- All records will be transported by the researcher from Clackamas Community College to Portland State University in a locked briefcase.

Your participation is voluntary. Participation or non-participation will not affect your grades and will not affect your relationship with PSU or CCC. 
If you have any questions or concerns about your participation in this study, contact Patricia DeTurk at Clackamas Community College, Harmony Campus - 7738 S.E. Harmony Road, Milwaukie, Oregon 97222, or at her number, 360-448-8529. If you have concerns about your rights as a research subject, please contact Research and Strategic Partnerships, Market Center Building $6^{\text {th }}$ floor, Portland State University, (503) 725-4288.

Your signature indicates that you have read and understand the above information and agree to take part in this study. The researcher should provide you a copy of this form for your own records.

Signature

Date

\section{Print Name}




\section{F. Exposure to Science Worksheets}

\section{F.1}

\section{UNIT 1: Hand Washing Exercise}

1. Wash your hands with warm, running water

2. Use soap to wash away germs; make a good lather

3. Wash hands for 20-30 seconds; rub vigorously (hint: hum "Happy Birthday song")

4. Be sure to wash front and back of hands

5. Always scrub under fingernails, under rings and between fingers

6. Rinse well with warm, running water, holding hands in a downward position, rinsing from wrists to fingertips

7. Dry your hands with a fresh paper towel

8. Use the paper towel to turn off faucet

Note: Do not use hot water; repeated exposure can increase risk of dermatitis

\section{When should you wash your hands?}

Before, during and after preparing food

Before eating

Before and after caring for someone who is sick

Before and after treating a cut or wound

After using the toilet

After changing diapers or cleaning up a child who has used a toilet

After blowing your nose, coughing or sneezing

After touching an animal or animal waste

After touching garbage

Alcohol-based hand sanitizers are okay to use when soap and clean water are not available. However, hand sanitizers are not effective with visibly dirty hands.

This exercise includes rubbing a special compound over the hands and observing your clean, washed hands under black light. Any parts of your hands not well washed will GLOW! Where did you see your hands glow?

Wash your hands again using proper technique and recheck your hands under the black light; do you see a difference?

What did you learn from this exercise? 


\section{F. Exposure to Science Worksheets}

\section{F.2}

\section{UNIT 2: Cheek Cells (Wet Mount)}

Introduction: Many things are viewed using a microscope, particularly cells. The internal parts of a cell can be difficult to see. Scientists choose certain stains to stain internal structures inside the cells.

\section{Objective:}

Demonstrate the proper procedures used in correctly using the compound light microscope

- Prepare and use a wet mount of living cells.

Materials:

- Microscope

- Saline with eyedropper

- Glass slides with cover slips

- Small tongue depressor

- Cheek cells

- Paper towel

Procedure:

1. Cells from the inside lining of your cheek are good for learning how to do wet mounts. Gently scrape inside of cheek with small tongue depressor.

2. Place cells on glass slide and mix with a drop of saline. Cover material with a cover slip. Repeat on second glass slide.

3. On one slide, place 1 drop of Methylene blue stain alongside the cover slip. The stain will flow under the cover slip and stain the cells.

4. Using the low power (10x) lens on your microscope, look at the unstained slide. Have your mentor show you how to use the coarse and fine adjustments on the microscope to focus.

5. Using high dry (40x), look at the unstained slide. Have your mentor show you how to use the fine adjustments on the microscope to focus.

6. Using the low power $(10 \mathrm{x})$ lens on your microscope, look at the stained slide. Draw what you see:

7. Using high dry (40x), look at the stained slide. Draw what you see: 


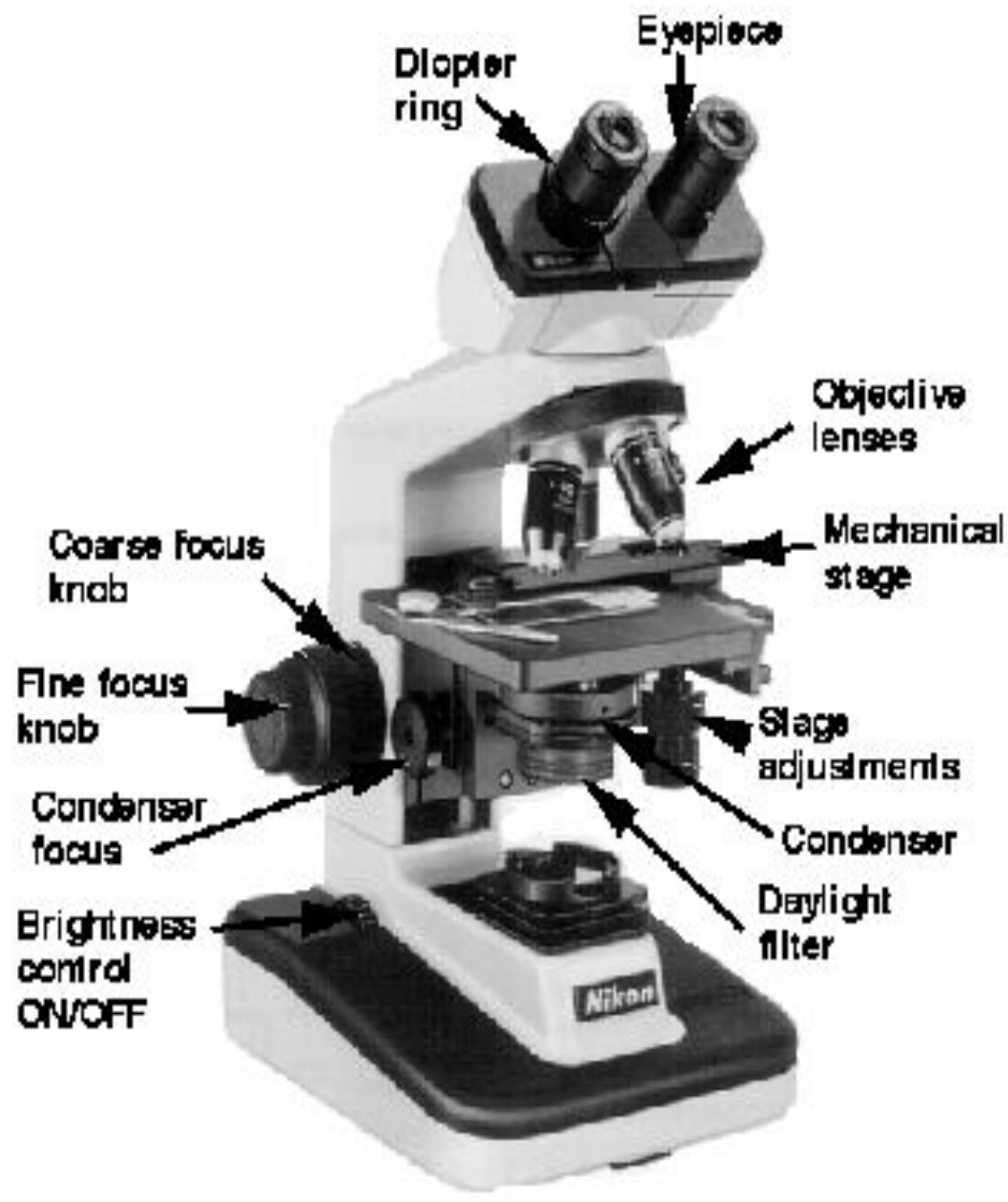




\section{F. Exposure to Science Worksheets}

\section{F.3}

\section{UNIT 3: Blood Cells (Prepared Slide)}

Introduction: Many things are viewed using a microscope, particularly cells. The internal parts of a cell can be difficult to see. Scientists choose certain stains to stain internal structures inside the cells. Here we are looking at blood cells which have been placed on a glass slide, dried and stained with a Wrights stain.

\section{Objective:}

- Demonstrate the proper procedures used in correctly using the compound light microscope

- Observe components of human blood under low and oil immersion (100x) magnification.

\section{Materials:}

- Microscope

- Prepared slide

- Immersion oil

- Lens cleaner

- Lens paper

\section{Procedure:}

1. Using the low power (10x) lens on your microscope, look at the prepared slide. Have your mentor show you how to use the coarse and fine adjustments on the microscope to focus. What do you see?

2. Using the oil immersion lens (100x), look at the stained slide. Have your mentor show you how to use the fine adjustments on the microscope to focus. Draw what you see: 


\section{G. GED Student Participant Demographics (Pilot/Formal Study)}

\begin{tabular}{|c|c|c|c|c|c|}
\hline \multicolumn{3}{|c|}{$\begin{array}{c}\text { Pilot Study Participant } \\
\text { Demographics }\end{array}$} & \multicolumn{3}{|c|}{$\begin{array}{c}\text { Formal Study Participant } \\
\text { Demographics }\end{array}$} \\
\hline Participant & $\#$ & $\%$ & & $\#$ & $\%$ \\
\hline Gender: Male & 4 & 40 & Gender: Male & 7 & 47 \\
\hline Female & 6 & 60 & Female & 8 & 53 \\
\hline Race: & & & Race: & & \\
\hline $\begin{array}{l}\text { American Indian/Alaskan } \\
\text { Native }\end{array}$ & 1 & 10 & $\begin{array}{l}\text { American Indian/Alaskan } \\
\text { Native }\end{array}$ & 1 & 7 \\
\hline Asian & 1 & 10 & Asian & 0 & 0 \\
\hline Black/African-American & 0 & 0 & Black/African-American & 0 & 0 \\
\hline Pacific Islander & 0 & 0 & Pacific Islander & 2 & 13 \\
\hline White & 8 & 80 & White & 12 & 80 \\
\hline Ethnicity: & & & Ethnicity: & & \\
\hline White, Hispanic & 2 & 20 & White, Hispanic & 3 & 20 \\
\hline White, Non-Hispanic & 6 & 60 & White, Non-Hispanic & 9 & 60 \\
\hline Disability Status: & & & Disability Status: & & \\
\hline Hearing Impaired & 0 & 0 & Hearing Impaired & 1 & 7 \\
\hline Visually Impaired & 0 & 0 & Visually Impaired & 0 & 0 \\
\hline Mobility Impaired & 0 & 0 & Mobility Impaired & 3 & 20 \\
\hline $\begin{array}{l}\text { Other (please specify): } \\
\text { COPD }\end{array}$ & 1 & 10 & Other (please specify): & 0 & 0 \\
\hline None & 9 & 90 & None & 11 & 73 \\
\hline
\end{tabular}

